\title{
A szénhidrogének primer migrációja
}

\author{
KoNCZ István
}

koncz.istvan38@chello.hu

\section{Primary migration of hydrocarbons}

\begin{abstract}
In this paper the author gives a summary of the primary migration of hydrocarbons taking place at shallower and greater depths. The expulsion of hydrocarbons from their sources requires rocks which are suitable in every respect (i.e. both quantity and quality). These rocks need to be at a lower thermal maturity, where the permeability of shales is still high enough to ensure that de-watering preserves the hydrostatic pressure. At greater depths, the pelites become overpressured due to their very low permeability, which does not allow the expulsion of hydrocarbons from the pores. If the overpressure reaches the actual horizontal stress, the microfracturing of shale takes place, allowing the expulsion of the generated hydrocarbons. Two examples are discussed in this study: primary migration from Middle Miocene sources and from the Endród Formation, respectively. It can be presumed that thin Middle Miocene sources were fractured by overpressure during the sedimentation of the Zagyva Formation. Following this event, the hydrocarbons migrated vertically to their present reservoirs at shallow depths and resulted in the Budafa and Lovászi fields. The thick Endrőd Formation proved to be a prolific source rock. However, based on the results of oil-to-source rock correlation, the hydrocarbons of this formation did not create accumulations in the Algyô structures on the western edge of the Makó-trench. It can be presumed that the microfracturing of the Endrőd Formation did not take place due to the early occurrence of overpressure. It is rather the case that the latter is associated with the generation of seals on both the top and bottom parts of the formation.
\end{abstract}

Keywords: hydrocarbons, primary migration, Middle Miocene sources, Endröd Formation, Hungary

Összefoglalás

A kisebb és nagyobb mélységben végbemenő primer migrációról közöl a szerző egy összefoglalást. A szénhidrogéneknek anyakőzeteikből történő kiszorulása minden szempontból (mennyiségileg és minőségileg egyaránt) nagyon jó anyakőzeteket igényel alacsony termikus érettség esetén, amikor a pelitek áteresztôképessége még mindig elég ahhoz, hogy a víz egy részének eltávozásával a hidrosztatikus nyomás fenn tudjon maradni. Nagyobb mélységben a pelitek túlnyomásossá válnak igen alacsony áteresztôképességük miatt, amely gátolja a pórusok fluidumainak kiszorulását. Ha a túlnyomás eléri a horizontális nyomást, a pelit megrepedezik, és lehetőséget ad a képződött szénhidrogének eltávozására. Ez a cikk két példát közöl: primer migráció középső-miocén anyakőzetekből és az Endrődi Formációból. Feltételezhető, hogy a vékony középső-miocén anyakőzetek a megfelelő mértékú túlnyomás létrejötte miatt repedtek meg, amikor a Zagyvai Formáció lerakódása zajlott. Ezt az eseményt követően a szénhidrogének vertikálisan migráltak a kisebb mélységben elhelyezkedő tárolóikba - létrehozva a Budafa és Lovászi mezôket. A vastag Endrődi Formáció jó anyakôzetnek bizonyult, de szénhidrogénjei nem képeztek felhalmozódásokat az Algyố szerkezeten a Makói-árok nyugati szegélyén az olaj-anyakőzet korreláció eredményei szerint. Feltételezhető, hogy az Endrődi Formáció megrepedése nem következett be a túlnyomás korai megjelenése és a zárórétegek miatt, amelyek a formáció tető és fekü részein jöttek létre.

Kulcsszavak: szénhidrogének, primer migráció, középsô-miocén anyakőzetek, Endrődi Formáció, Magyarország 


\section{Bevezetés}

A cikk tárgya kizárólag a primer migráció, amelynek folyamán a képződött szénhidrogének egy része eltávozik az anyakőzetéból. A szekunder migrációt a cikk nem tárgyalja. $\mathrm{Az}$ anyakőzetek litológiai jellege a törmelékes kőzetekre korlátozódik, mert a rendelkezésre álló adatok csak a törmelékes kőzetekre vonatkoznak. A nagy karbonáttartalmú anyakőzetek viselkedése eltér a törmelékesekétől.

\section{A migráció fogalma}

Az anyakôzetek szerves anyagából megfelelő mértékben magas hőmérsékleten képződött szénhidrogének anyakőzeteikből való eltávozása (kiszorulása) a primer migráció. A primer migráció szerepe akkor vált ismertté, amikor kiderült, hogy a kőolaj- és földgáz-felhalmozódásokat tartalmazó durvaszemcsés törmelékes kőzetek, az ún. tárolókőzetek nem tartalmaznak annyi szerves anyagot, amennyi a jelentős készletû telepek jelenlétét indokolná. A tárolókőzetekkel szemben a finomszemcsés törmelékes kőzetek, a pelitek, amelyekben általában nincs szénhidrogén-felhalmozódás, jóval több szerves anyagot tartalmaznak (HuNT \& JAMIESON 1956, RoNOV 1958). ( A kőzetek szerves anyaga menynyiségének jellemzésére a szerves széntartalom (TOC \%) szolgált.) A pelitek tehát a szénhidrogének anyakőzeteinek tekinthetôk. Ahhoz, hogy a pelitekben képződött szénhidrogének a durvaszemcsés kőzetekbe kerülve a szekunder migráció eredményeként a szerkezetekben felhalmozódásokat tudjanak képezni, a pelitekból a szénhidrogéneknek a primer migráció folyamata során, legalábbis részben, el kell tudniuk távozni. A szekunder migrációban részt vevő folyamatok törvényszerúségeit eléggé korán, már az ötvenes években felismerték (HuBBERT 1953, HoBson 1954). Tisztázták a gáz, illetve az olaj, valamint a víz sûrúségkülönbségéből adódó felhajtóerô, a kapilláris nyomás és a hidrodinamikai nyomásgradiens szerepét a fluidumok mozgásában. A primer migráció alapvető folyamatait illetően csak a nyolcvanas években sikerült megegyezésre jutni (DURAND 1987). A primer migráció mechanizmusa viszonylag kis mélységben és a nagyobb mélységekben eltérô. Kis mélységben a pelitek és a tárolókőzetek eltérő mértékű tömörödéséből (differenciális kompakciójából) jön létre az a nyomásgradiens, amely a pelitekből a velük közvetlenül érintkezô, migrációs vezetô közegként múködő tároló típusú kőzetekbe juttatja a képződött szénhidrogéneket. Az olaj és a víz sûrûségkülönbségéből adódó felhajtóerô ugyanis jóval kisebb, mint a finomszemú üledékekben érvényesülő kapilláris nyomás. A primer migrációban az olaj csak a víztôl elkülönült fázisban képes mozogni, a gázfázisban lévô szénhidrogének pedig vízben oldott állapotban is migrálhatnak (MAGARA 1980, DuRAND 1983). Nagyobb mélységben fôleg a peliteknek a megfelelő mértékú túlnyomás által létrehozott megrepedezettsége (microfracturing) révén tudnak távozni anyakőzeteikből a szénhidrogének (MAGARA 1981, PRICE 1994).
A következőkben a primer migráció folyamatának elméleti kérdéseivel foglalkozunk, majd a középső-miocén képződményekből és az Endrődi Formációból történt migrációt tárgyaljuk.

\section{A primer migráció folyamata és hatótényezói}

Egy medencében a folyamatos üledékképződés során a kôzetek egyre nagyobb mélységbe kerülnek. A kőzetfelületre a fedő rétegeknek a gravitációs erôtérben a tömegükből adódó, vertikális irányú litosztatikus nyomása (L) hat, amely összenyomni igyekszik a kőzetet, annak térfogatcsökkenését (kompakcióját) idézve elő (1. ábra). A kőzetre ható litosztatikus nyomás az üledékképződés során - egy kiválasztott kőzetelemet tekintve - nő, amelyet $23 \mathrm{MPa}$ (megapascal)/km gradiens jellemez a kőzettömeg átlagos

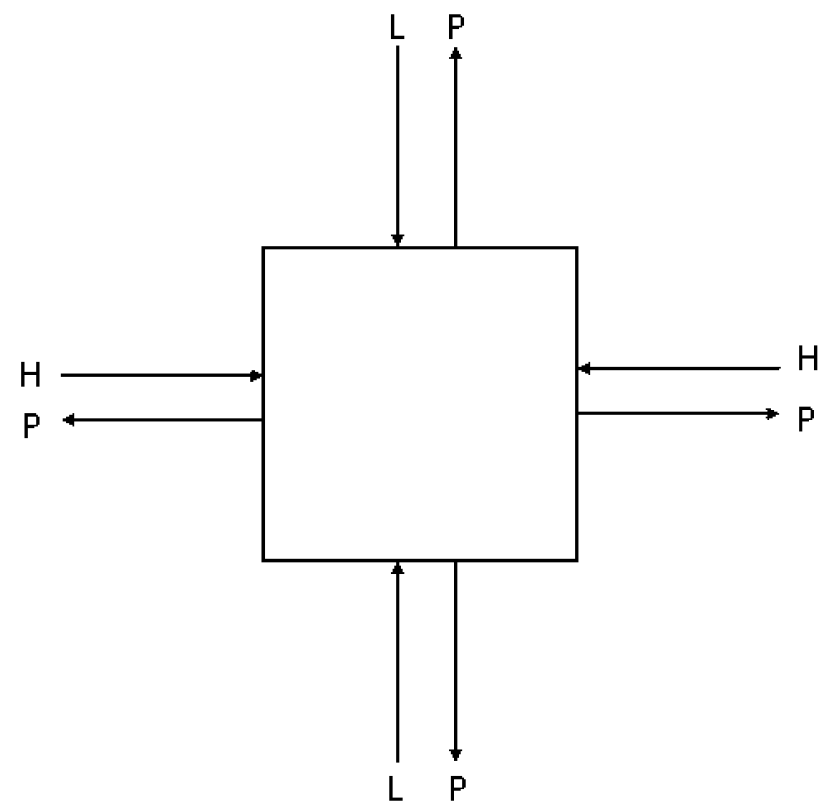

1. ábra. A kőzetek felületére ható erők

Figure 1. Pressures acting rocks

sûrûségéből (2,3t/m³) adódóan. Egy medence üledékekkel való feltöltődése során a litosztatikus nyomás növekedése okozza az áteresztőképesség és a porozitás csökkenését. A litosztatikus nyomás deformáló hatását horizontális irányban a horizontális feszültség $(\mathrm{H})$ ellensúlyozza. A pórusfolyadék nyomása $(\mathrm{P})$ minden irányban hat. Egészen addig, amíg a kőzetek áteresztőképessége még elég nagy ahhoz, hogy nagy üledékképződési sebesség esetén is biztosítani tudja a hidrosztatikus nyomás $(\mathrm{N})$ megmaradását a pórustér fluidumainak kipréselődése során, a pórusokban elhelyezkedő, teljesen vízből álló fluidum nyomásgradiense a víz sưrúségéből $\left(1 \mathrm{t} / \mathrm{m}^{3}\right)$ adódóan $10 \mathrm{MPa} / \mathrm{km}$, és változatlan marad. A normális, hidrosztatikus állapotot jelzô mélységtrend (N) az OA szakasznak felel meg, és a felszíntől az „A” pontnak megfelelő mélységig tart (2. ábra). Ebben a mélységtartományban a fluidumnyomás $(\mathrm{P})$ még a pelitek póru- 


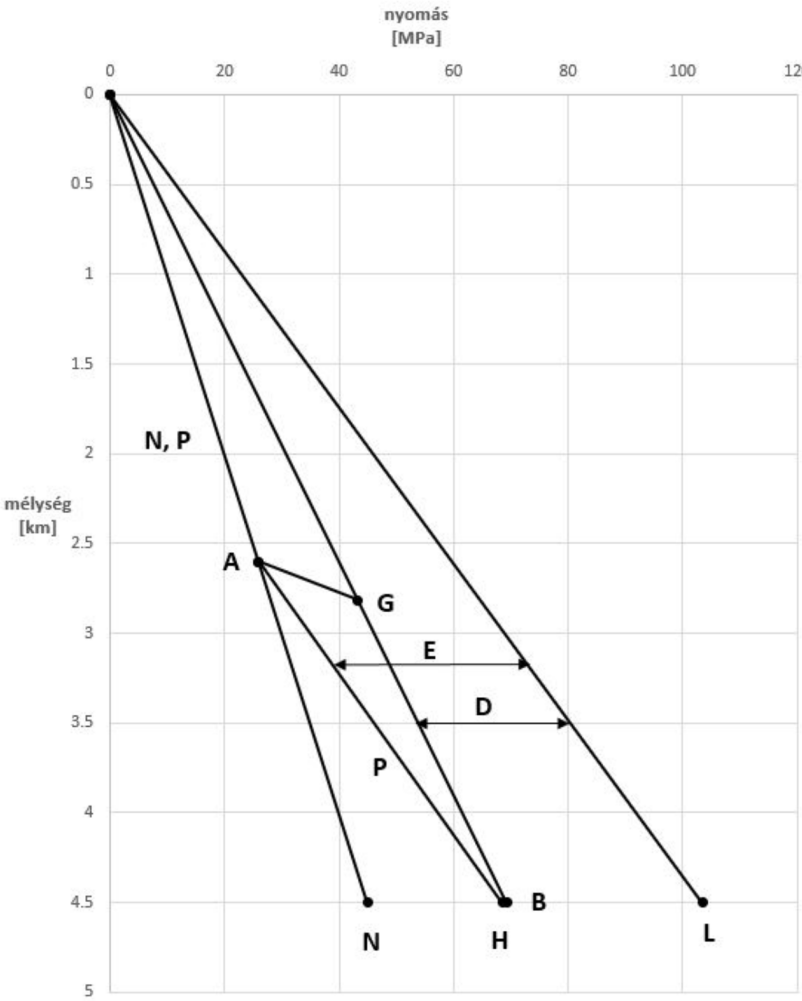

2. ábra. A nyomás és a mélység közötti összefüggések

Figure 2. Relationships between pressure and depth

saiban is idővel hidrosztatikus marad: az N és a P mélységtrend azonos. A kőzetek pórustereiben lévő víz kiszorulását adott mélységben a litosztatikus nyomás (L) és a hidrosztatikus nyomás $(\mathrm{N})$ különbsége idézi elô. Az említett nyomáskülönbség (L-N) gradiense $13 \mathrm{MPa} / \mathrm{km}$ : a $23 \mathrm{MPa} / \mathrm{km}$ és a $10 \mathrm{MPa} / \mathrm{km}$ különbsége.

Az effektív porozitás 100 méterenkénti átlagértékeit (trendpontjait) a pelitekre (p) és a homokkövekre (h) vonatkozóan a 3. ábra szemlélteti a DK-alföldi neogén süllyedékekben (SZALAY 1982). (Az effektív porozitás az egymással áramlástani kapcsolatban lévő pórustereket jellemzi.) Az említett ábrán a porozitás (\%) értékek (pórustérfogat/100 egység kőzettérfogat) logaritmusa szerepel, amely egyes mélységszakaszokban lineáris összefüggést mutat a mélységgel, mert a porozitás ( $\phi \%)$ a mélységgel (z) a következő típusú összefüggésben van: $\phi=\phi_{\mathrm{o}}^{-\mathrm{a} z}$, ahol $\phi_{\mathrm{o}} \mathrm{a} z=\mathrm{o}$ mélységhez tartozó porozitás, az ,a” pedig konstans. A porozitás csökkenése a fedőréteg terhelési nyomása hatására majdnem teljes egészében irreverzibilis folyamat (MILLER et al. 2002). A DK-alföldi neogén süllyedékek esetében a homokkövek porozitása (h) 1,7-4,8 km mélységintervallumban eltérô meredekségú, de folyamatos csökkenést mutat. A pelitek porozitása (p) 2,6 km mélységig csökken, ennél nagyobb mélységben csökkenése lassul olyannyira, hogy a porozitás gyakorlatilag változatlan marad. A pelitek porozitásának mélység szerinti változása arra utal, hogy 2,6 km mélységtôl kezdődően a fluidumok kevésbé tudnak kiszorulni a pórusokból: a pórusok fluidumainak mozgás-

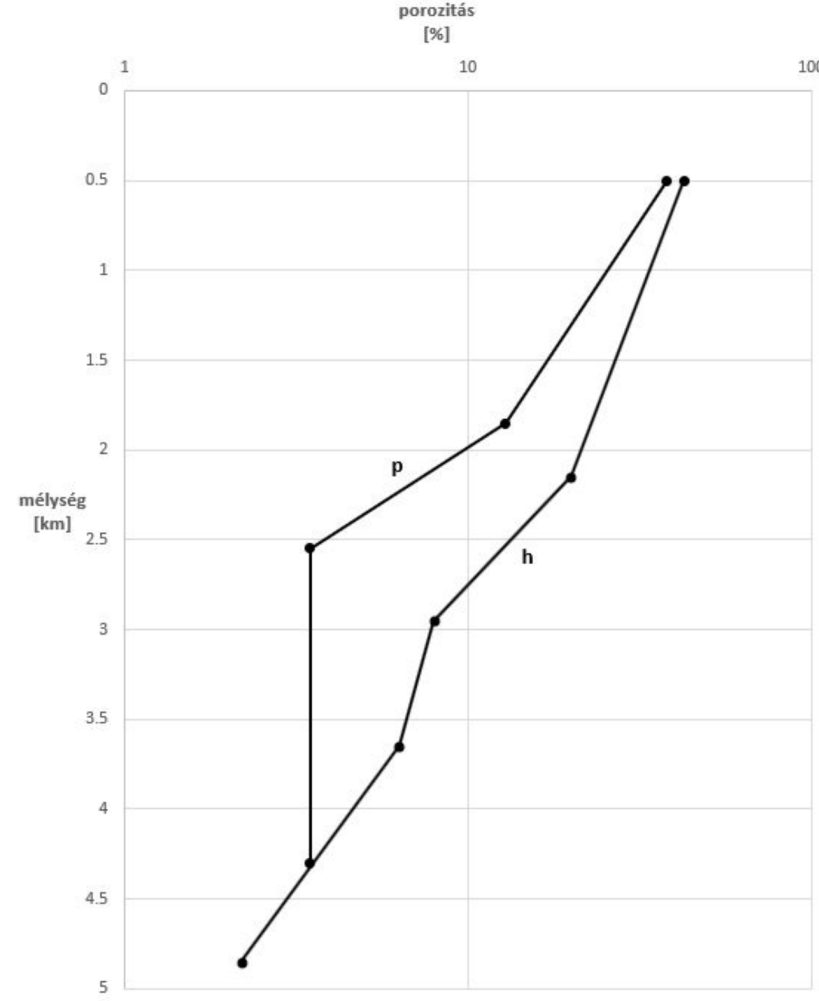

3. ábra A homokkövek (h) és a pelitek (p) porozitásváltozása a mélységgel Figure 3. Porosity-changes of sandstones ( $h$ ) and pelites (p) through depth

lehetőségei korlátozottá válnak, a pórustartalom egyre nagyobb mértékben izolálttá, a kompakció gátolttá válik. Ezért adott esetben - a 2,6 km mélységet a DK-alföldi neogén süllyedékek esetében izolációs mélységnek tekinthetjük. A gátolt kompakció különböző mélységértékeknél alakulhat ki. Az alacsony áteresztőképesség mellett döntő hatást gyakorol a gátolt kompakció kialakulásának mélységére az, ha az üledékképződés gyors, nagy ütemú. Nagy üledékképződési ütem esetén a gátolt kompakció a 2,6km mélységnél kisebb mélységben is megvalósulhat. A felszíntől 2,6 km mélységig a pelitekben egyensúlyi, hidrosztatikus viszonyokat megtartó tömörödés (kompakció) megy végbe, ennél nagyobb mélységben a nem egyensúlyi, túlnyomást előidéző kompakció válik jellemzővé.

A pelitek függóleges (p) és a homokkövek vízszintes (h) irányú áteresztőképességének 100 méterenkénti átlagértékeit (trendpontjait) szemlélteti a 4. ábra mD (millidarcy, $10^{-15}$ $\mathrm{m}^{2}$ ) egységekben (SzALAY 1982). A különböző irányú áteresztôképesség alkalmazását az indokolja, hogy egy pelitek és homokkövek váltakozásából álló rétegsorban a tömörödés (kompakció) során a pelitekből inkább a rétegződésre meróleges irányban távozik a fluidum, a homokkövekből a rétegződéssel párhuzamosan, vízszintes irányban (MAGARA 1976). A porozitáshoz hasonlóan az áteresztőképesség logaritmusa szerepel a 4. ábrán, mert így egyes szakaszokban lineáris a mélységgel való összefüggés. (A pelitek $0,1 \mathrm{mD}$ értéknél kisebb áteresztőképességének mérése technikailag nehézkes és bizonytalan eredményeket szolgáltató. Feltéte- 


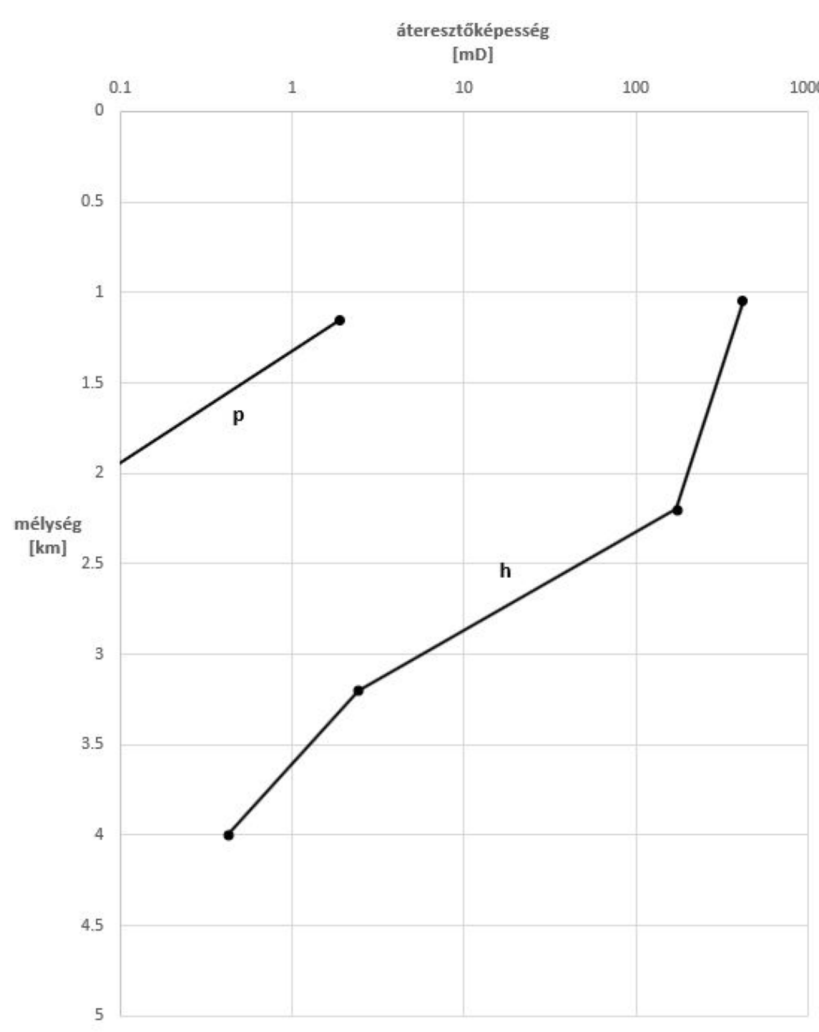

4. ábra. A homokkövek vízszintes (h) és a pelitek függőleges (p) áteresztőképességének változása a mélységgel

Figure 4. Horizontal permeability of sandstones $(h)$ and vertical permeability of pelites ( $p$ ) vs. depth

lezhető, hogy a 4. ábrán látható, pelitekre vonatkozó mélységtrend a nagyobb mélységek irányában folytatódik, de 2,6 km mélységtől kezdődően, a porozitáshoz hasonlóan állandósul.)

A kőzeteken keresztül a nyomásgradiens hatására végbemenő fluidummozgást a Darcy-törvény írja le:

$$
\mathrm{Q}=[\mathrm{A} /(\mathrm{L} \times \mu)] \times \mathrm{k} \times \Delta \mathrm{P}
$$

(Q - a fluidummozgás sebessége, térfogatáram, $\mathrm{m}^{3} / \mathrm{s} ; \mathrm{A}$ - a fluidumot átbocsátó kőzetfelület, $\mathrm{m}^{2} ; \mathrm{L}$ - a fluidumot átbocsátó kőzetelem hossza, $\mathrm{m} ; \mu$ - a fluidum dinamikus viszkozitása, Pa × s (pascalszekundum); $\mathrm{k}$ - a kőzet áteresztôképessége, $\mathrm{m}^{2} ; \Delta \mathrm{P}$ - nyomáskülönbség (esetünkben: $\mathrm{L}-\mathrm{N}, \mathrm{Pa}$.) A nyomáskülönbség (L-N) által előidézett fluidum térfogatáram (Q) adott mélységben a kôzet hidraulikus potenciálja, ami kis mélységben, ahol az áteresztőképesség még jelentékeny $(>0,1 \mathrm{mD})$ a pelitekben is, viszonylag rövid időn belül elérve a hidrosztatikus nyomást $(\mathrm{N})$, kimerül. Ennek a folyamatnak az időbeli lefolyása azonban a jóval kisebb áteresztôképességú pelitekben igen lassú a homokkövekéhez viszonyítva. Ugyanazon mélységben a pelitek függőleges $\left(\mathrm{k}_{\mathrm{p}}\right)$ és a homokkövek vízszintes $\left(\mathrm{k}_{\mathrm{h}}\right)$ áteresztőképességének aránya $\left(\mathrm{k}_{\mathrm{p}} / \mathrm{k}_{\mathrm{h}}\right)$ megegyezik a pelitek és homokkövek hidraulikus potenciálja arányával $\left(\mathrm{Q}_{\mathrm{p}} / \mathrm{Q}_{\mathrm{h}}\right)$ (MAGARA 1976). A $\mathrm{k}_{\mathrm{p}} / \mathrm{k}_{\mathrm{h}}$ áteresztőképesség-arány a DK-alföldi neogén süllyedékek 1,2-1,9 km mélységtartományában $4,19 \times 10^{-3}$ és $5,5 \times 10^{-4}$ értékek közötti (5.ábra). A $\mathrm{k}_{\mathrm{p}} / \mathrm{k}_{\mathrm{h}}$ áteresztőképesség-arány az előbbiek szerint ugyanazon mélységben a hidraulikus poten-

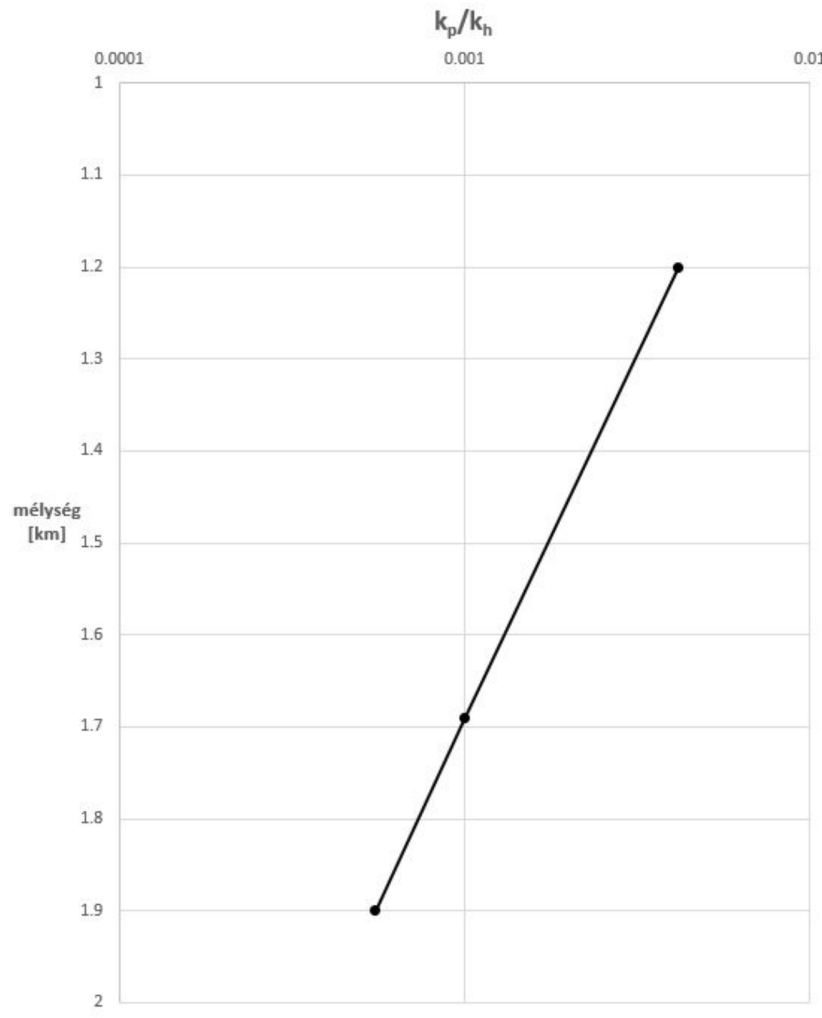

5. ábra. A kp/kh arányok változása a mélységgel

Figure 5. $\mathrm{kp} / \mathrm{kh}$ ratios $v$. depth

ciálaránnyal egyezik. Az egységnyi idő alatt kiszorult fluidum térfogatával $(\mathrm{Q})$ arányos a nyomás csökkenése. Ezért, például, a $\mathrm{k}_{\mathrm{p}} / \mathrm{k}_{\mathrm{h}}$ áteresztôképesség-arány 0,001 értéke 1,69 km mélységben azt jelenti, hogy azonos idő alatt a pelitekben a nyomáscsökkenés ezredrésze a homokkövekében elért nyomáscsökkenésnek: azaz egy ideig a nyomás a pelitekben nagyobb, mint a homokkövekben. Ez az idővel csökkenő, a differenciális kompakcióból eredó nyomáskülönbség a fố hajtóereje a pelitekból a velük közvetlenül érintkező homokkövekbe irányuló, vizes közegű primer migrációnak az olajra ható felhajtóerôn kívül (MAGARA 1980).

A vizes közegú és hidrosztatikus nyomásviszonyokkal jellemezhető primer migráció során a pelitekben képződött olaj a víztől elkülönült fázisban képes mozgásra, ha a pórustérben elegendő arányú az olaj jelenléte: azaz szükséges egy minimális olajtelítettség elérése a pórusokban (MAGARA 1978). Ennek megértését szolgálja a 6. ábra „a” része, amely bemutatja a víztől elkülönült fázis, az olaj $\left(\mathrm{k}_{\mathrm{ro}}\right)$ és a víz relatív áteresztôképességének $\left(\mathrm{k}_{\mathrm{rv}}\right)$ változását a víztôl elkülönült fázisnak (az olajnak) a pórustérben érvényesülő telítettsége (S \%) függvényében (SHANLEY et al. 2004). Ha az olaj telítettsége az „A” pontnak megfelelőnél kisebb, akkor az olaj telítettsége irreducibilis (nem redukálható) az „I” jelû szakaszban. Ha az olaj telítettsége az „A” és „B” pontok közötti („II” jelú szakasz), akkor csak a víz képes mozogni, az olaj még nem. Az eltávozó víz csökkenti a víztelítettséget, és növeli az olajtelítettséget. Ha az olaj telí- 
a.

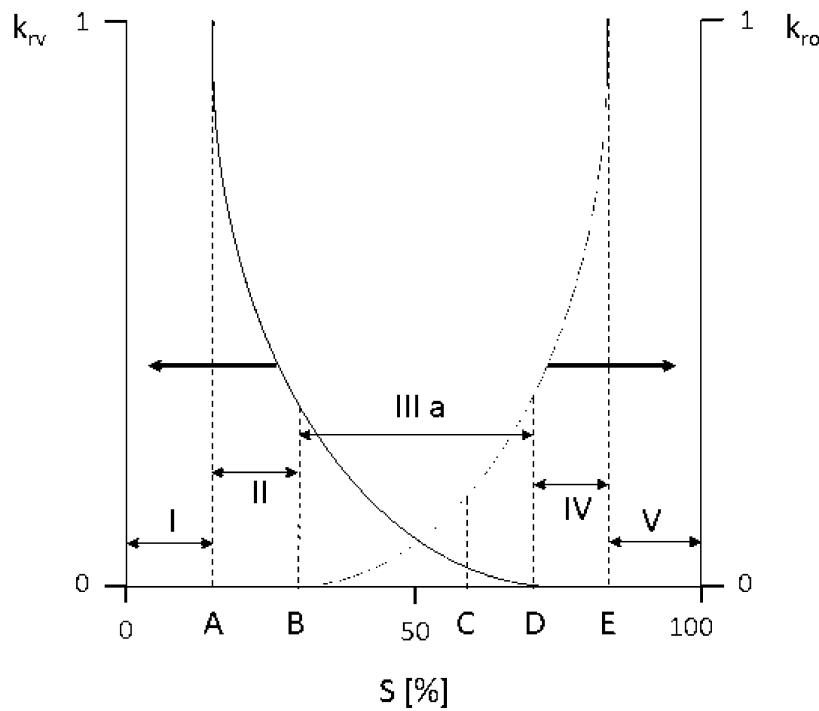

b.

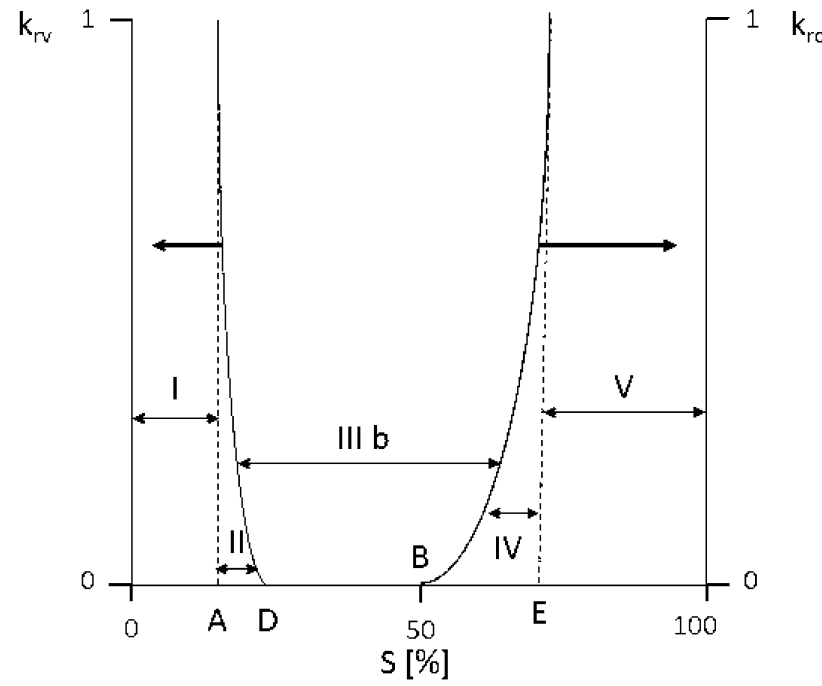

6. ábra. Relatív áteresztőképesség kisebb mélységben (a) és nagyobb mélységben (b) (SHANLEY 2004)

Figure 6. Relative permeability at shallower (a) and greater (b) depths (SHANLEY 2004)

tettsége eléri a $20 \%$ értéket (a „B” pontot), akkor az olaj is tud mozogni a vízzel együtt a „III a” jelú szakaszban (DURAND 1987). A „C” pont azt a helyzetet szemlélteti, amikor a vízkiáramlás miatt csökkent víztelítettség megnöveli az olaj telítettségét, illetve az kétfázisú áramlásban nô az olaj részvétele. A „D” ponttól kezdve már csak az olaj mozoghat az „E” pontig terjedő „IV” jelű szakaszban, a víz nem. Az „E” pontnál nagyobb olajtelítettség már nem jár együtt az olajmozgás lehetôségének növekedésével, mert az „,V” jelű szakaszban a víztelítettség irreducibilis.

A kérdés az, hogy mekkora eséllyel fordulhat elő a vizes közegú és hidrosztatikus nyomásviszonyokkal jellemezhető primer migráció során a felszíntôl a 2,6km mélységig tartó szakaszban az az olajtelítettség, amely lehetôvé teszi - az olajra ható felhajtóerőn túlmenően - az olaj mozgását, eltá- vozását a pelitből a vízzel együtt. A hazai neogén süllyedékekben 2,6 km mélységben a szerves anyag érettségét mutató vitrinitreflexió általában kicsiny, csak 0,6\% értéket ér el, ami arra utal, hogy a szerves anyag termikus átalakultsága alacsony szintû. Ha képződik is olaj, akkor telítettsége általában nem érheti el az olaj mozgásához szükséges minimális értéket. Kivételt képez, amikor a pelitek szerves anyagának mennyisége, szervesszén-tartalma (TOC \%) és a RockEval mérésekkel megállapítható kezdeti minősége, hidrogénindexe (mg CH/g TOC) igen kedvező, magas érték. (Itt meg kell jegyezni, hogy a mért értékek csak kissé alacsonyabbak, mint a kezdetiek, ha a termikus érettség még elegendő mértékben alacsony.) Ez a kivételes állapot a következő összefüggés figyelembevételével érzékeltethető:

(képzôdött olaj, kg/tonna kőzet $)=($ átalakulási arány $) \times$ (szénhidrogén-potenciál, kg/tonna kőzet)

A szénhidrogén-potenciál azon szénhidrogének menynyiségének maximumát jelenti, amelyek a kőzet szerves anyagából képződhettek a termikusan éretlen állapottól kezdődően és a túlérettel befejezőleg. A 0-1 tartományú átalakulási arány a termikus érettség növekedésével nő, a szénhidrogénpotenciál teljes mértékú kimerülése esetén éri el az 1 értéket. Belátható, hogy a képződött olaj mennyisége a kőzetben az átalakulási arány és a szénhidrogén-potenciál szorzata kell legyen. Tételezzük fel, hogy az átalakulási arány 0,05, ami a termikusan éretlen szerves anyagnak megfelelően alacsony. Ha a pelit szénhidrogén-potenciálja $1 \mathrm{~kg}$ szénhidrogén/tonna kôzet, akkor a fentiek szerint a képződött olaj 0,05 kg olaj/tonna kőzet koncentrációt ér el. Ha a pelit szénhidrogén-potenciálja $20 \mathrm{~kg}$ szénhidrogén/tonna kőzet (az előbbi hússzorosa), akkor ugyanazon átalakulási arány $(0,05)$, illetve termikus érettség esetén a képződött olaj koncentrációja $1 \mathrm{~kg}$ olaj/tonna kőzet, nyilvánvalóan az előbbi húszszorosa. (Az 1 kg/tonna kőzet szénhidrogén-potenciál megfelel egy olyan pelitnek, amelynek szervesszén-tartalma 0,5\%, hidrogénindexe $200 \mathrm{mg} \mathrm{CH} / \mathrm{g}$ TOC. A $20 \mathrm{~kg} /$ tonna kőzet szénhidrogén-potenciál olyan pelitet képvisel, amelynek szervesszén-tartalma 5\%, hidrogénindexe $400 \mathrm{mg} / \mathrm{g}$ TOC). Az olaj mozgását a pelitrétegen belül a kapilláris erôk gátolják. A pelitréteg homokkővel érintkezô részén az olaj könnyen belép a homokkőbe, mert a homokkő kapilláris nyomása jóval kisebb, mint a peliteké.

Az előzőek alapján a képződött olaj vizes közegú migráció révén történő eltávozása a viszonylag alacsony termikus érettségú pelitekből abban az esetben mehet végbe, ha elegendô mennyiségú olaj keletkezett. Ez csak akkor következik be, ha a pelit mint anyakőzet minőségileg és mennyiségileg kitűnő. Tehát, eléggé esetleges ilyen körülmények között az olaj primer migrációjának bekövetkezése. Eléggé általános viszont a bakteriális eredetû metán eltávozása a pelitekből vízben oldott állapotban, mert a bakteriális eredetú metán képződésének hőmérséklet-tartományához $\left(<80{ }^{\circ} \mathrm{C}\right)$ tartozó mélységtartomány megfelel az egyensúlyi, hidrosztatikus nyomással rendelkező, nem gátolt kompakciónak.

Kis mélységben a pelitek kompakciója általában egyensúlyi természetû, azaz a hidrosztatikus nyomás megôrződik. 
Ez azonban csak a vékony pelitrétegekre, illetve olyan pelittestekre igaz, amelyek tagoltak homokkövekkel. A vastagabb pelitrétegek homokkövekkel érintkező szegélyében nem gátolt a kompakció, így ott az áteresztőképesség nagymértékben csökken, és a porozitás is kisebbé válik: a hidrosztatikus nyomás fennmarad. A vastagabb pelitrétegeknek a homokkövekkel érintkező felületi része ennélfogva akadályozza a pelit belsejéből történő vízkiszorulást: a vastagabb pelitrétegek belsejében a hidrosztatikust meghaladó nyomás, túlnyomás jön létre (SZALAY 1982). A vastag, homokkövekkel nem tagolt pelittestekből így tömegükhöz, illetve a bennük képződött szénhidrogének tömegéhez képest kevés szénhidrogén képes távozni részben azért, mert a homokkövekkel érintkező felülete viszonylag kicsiny, továbbá mert az említett homokkövekkel érintkező részük meggátolja a pelittest belsejéből a szénhidrogének eltávozását (BROOKS et al. 1987).

A délkelet-alföldi neogén süllyedékekben 2,6km mélységtôl kezdődően a pelitek porozitása tovább már nem csökken, mert a pórustér fluiduma nem képes eltávozni az igen alacsony áteresztőképesség miatt (3. ábra). Ebben a mélységben a pelitek függőleges áteresztőképességének mélységfüggése (4. ábra) alapján extrapolált áteresztôképesség $8,5 \mu \mathrm{D}$ (mikrodarcy, $8,5 \times 10^{-18} \mathrm{~m}^{2}$ ). Indokoltan feltételezhetô, hogy 2,6 km mélységtől kezdődően a pelitek áteresztőképessége - a porozitáshoz hasonlóan - a mélység növekedésével kevéssé változik a nem egyensúlyi, gátolt kompakció eredményeként. Ha a pórustér fluiduma áramlási szempontból teljesen izolálttá válik, akkor egyáltalán nem szorul ki a fluidum a pórustérből az üledékképződés folytatódása során a mélységgel növekvő litosztatikus nyomás (L) hatására. Ezt a megnövekedett nyomást a pórustér fluiduma kénytelen követni a litosztatikus trendvonallal (L) párhuzamosan: azaz a pelit túlnyomásossá válik. A 2. ábrán feltüntetett hidrosztatikus trendvonal $(\mathrm{N})$,A" pontjától, 2,6 km mélységtől kezdődően a pórustér fluidumának nyomása (P) nagyobb lesz mint ugyanabban a mélységben a hidrosztatikus nyomás $(\mathrm{N})$. Az ilyen módon kialakult túlnyomás a nem egyensúlyi, gátolt tömörödés (kompakció) következménye, ami az alacsony áteresztôképesség miatt jön létre. TERZAGHI (1923) szerint a litosztatikus nyomás (L) és a pórusfolyadék nyomásának (P) különbsége az effektív nyomás, feszültség, vagy stress (E) (2. ábra):

$$
\mathrm{E}=\mathrm{L}-\mathrm{P}
$$

Az effektív nyomás (E) a 2,6 km mélységig a litosztatikus (L) és a hidrosztatikus nyomás $(\mathrm{N})$ különbsége. A hidrosztatikus nyomás a 0-2,6 km mélységintervallumban azonos a pórustér fluidumának nyomásával (P). 2,6 km mélységig az effektív nyomás (E) a mélységgel nő, ettôl kezdődően azonban nem változik, állandó marad (7. ábra).

A kőzet felületére nemcsak a fedő réteg terhelésből adódó litosztatikus nyomása (L) hat, hanem a horizontális irányú $(\mathrm{H})$ is (1. ábra). A horizontális nyomás (feszültség, stress) ,ellentart” a litosztatikus nyomás által kikényszerített deformációnak, amely függőleges irányban a kőzetet összenyomni, hosszát rövidíteni, vízszintes irányban kiter-

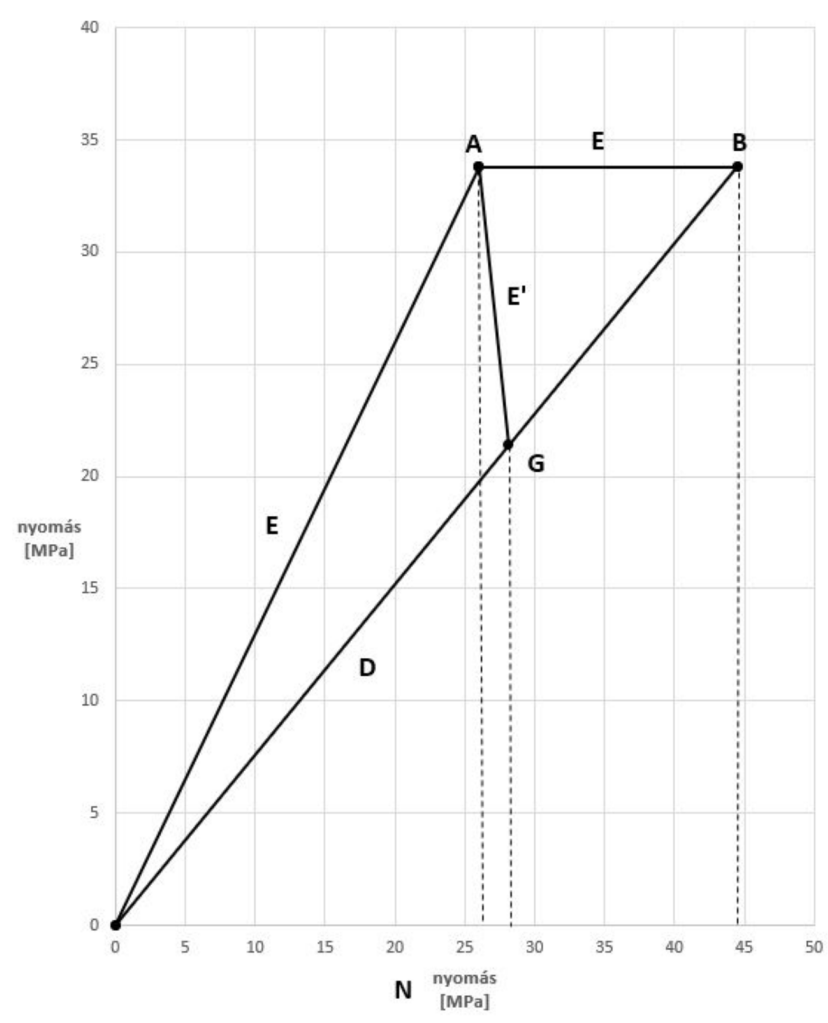

7. ábra. Az effektív nyomás (E), valamint a differenciális nyomás (D) és a hidrosztatikus nyomás közötti összefüggések

Figure 7. Relationships between effective and differential stresses, and hydrostatic pressure

jedését növelni igyekszik. Ha a földtani környezetben a vízszintes irányban ható tektonikai eredetû nyomás (feszültség) elhanyagolható, akkor a litosztatikus nyomás (L) és a horizontális nyomás $(\mathrm{H})$ között a következő összefüggés van (RouCHET 1981):

$$
\mathrm{H}=\mathrm{L} /(\mathrm{m}-1)
$$

Az „m” a Poisson-szám, a Poisson-arány reciproka. A Poisson-arány egy kőzettest vízszintes (laterális) és függôleges alak-, illetve térfogatváltozásának aránya a függőleges irányú nyomás, esetünkben a litosztatikus nyomás (L) hatására. Minél nagyobb a Poisson-arány, a kőzettest annál inkább „kihasasodik”, miközben a hosszanti (függóleges) irányban zsugorodik. A pelitekre jellemző Poisson arány 0,4, amelynek megfelelően a Poisson-szám 2,50 (RoUCHET 1981). A horizontális (H) és a litosztatikus (L) nyomás közötti összefüggés a pelitekben a fentieket alkalmazva a következő:

$$
\mathrm{H}=0,67 \times \mathrm{L}
$$

Mivel a litosztatikus nyomás (L) mélységgradiense 23 $\mathrm{MPa} / \mathrm{km}$, a horizontálisé $(\mathrm{H})$, akkor a következő:

$$
\mathrm{L}=0,67 \times 23=15,4 \mathrm{MPa} / \mathrm{km}
$$

Ennek az összefüggésnek megfelelő trendvonal $(\mathrm{H})$ a litosztatikus (L) és a hidrosztatikus $(\mathrm{N})$ trendvonal közé esik (2. ábra). Továbbá szerepel a 2. ábrán a litosztatikus nyomás és a fluidumnyomás különbsége (L-P), az effektív nyomás (E), valamint a litosztatikus nyomás és a horizontális nyo- 
más különbsége (L-H), a differenciális nyomás, feszültség, vagy stress (D). A 7. ábrán az effektív nyomás (E) és a differenciális nyomás, feszültség, vagy stress (D) változása látható a hidrosztatikus nyomás (N) függvényében.

A pelitekben 2,6 km mélységtől kezdődôen kialakult hidrosztatikusnál nagyobb nyomás a litosztatikus nyomás mélységgradiensével (L) párhuzamosan növekszik, ha a pelitek pórusaiban lévő folyadék áramlástani szempontból teljes mértékben izolálttá vált (2. ábra). Ebben a túlnyomásos, „A" ponttól kiinduló szakaszban a fluidum nyomása $(\mathrm{P})$ elérheti a kôzet felületére ható nyomások közül a kisebbet, a horizontális nyomást $(\mathrm{H})$ a „B” pontban $(\mathrm{P}=\mathrm{H})$. (A fluidum nyomásának - elvileg - nemcsak a horizontális nyomást kell elérnie, hanem a horizontális nyomásnak és a pelit húzószilárdságának összegét [RouCHET 1981]). A pelitek húzószilárdsága azonban kicsiny (maximum $2 \mathrm{MPa}$ ), így elhanyagolható (SOMOSVÁRI 1987). Tulajdonképpen a fluidumnyomás kompenzálja azt az erôt, amely kőzet felületére hatva biztosította a kôzetváz megmaradását a „B” pontnak megfelelő mélység eléréséig (MAGARA 1981). A „B” pontnak megfelelő fluidumnyomás $4,45 \mathrm{~km}$ mélységben megrepeszti a pelitet, amelynek következtében - függetlenül a pelit mint anyakőzet mennyiségi és minôségi jellemzôitől - a pórusfolyadék, a víz és a képződött olaj egy része a pelitet övezó homokkőrétegekbe „fejtôdik át” a relatív áteresztôképességi viszonyoknak megfelelóen: megvalósul a primer migráció a nem egyensúlyi kompakciónak megfelelő állapotban, a vizes közegú, egyensúlyi kompakció mélységtartományánál jóval nagyobb mélységben. A pelit fluidumtartalmának hirtelen eltávozása a pelit térfogatának csökkenését idézi elő, ami az ún. kompakciós vetók képződéséhez vezethet. A kompakciós vetôk migrációs utakat nyithatnak meg a kisebb mélységben lévő tárolókőzetek felé. A hazai, viszonylag kis mélységben lévő tárolók felhalmozódásainak egy része ilyen módon, vetőkön keresztül végbemenő vertikális migráció révén jöhetett létre (KoNCZ 2019a). A „B” pontnak megfelelő hidrosztatikus nyomásnál $\left(\mathrm{N}_{\mathrm{B}}\right)$ az effektív (E) és a differenciális (D) nyomás, feszültség, vagy stress megegyező értékú (7. ábra). Belátható. hogy ez azt is jelenti, hogy a fluidumnyomás (P) egyenlő a horizontális nyomással (H). A pelit megrepedését és a fluidumkiáramlást követően a pelit tömörödik (kompaktálódik) az újbóli, nagyobb mélységben bekövetkező megrepedésig (HuNT 1990). Az újólagos megrepedés feltételezése révén lehetett megmagyarázni az Algyő többtelepes előfordulásban az olajok könnyú és nehéz részének érettségében mutatkozó különbségeit (KONCZ 2018). A modellezések eredményei is ismételt felrepedést mutattak (OZKAYA 1984, PAYNE et al. 2000). Az előzőekben említett mélységtrendek lineárisak voltak. A mélységtrendek nem lineáris voltára utaltak a modellezés eredményei kapcsán (PAYNE et al. 2000). A litosztatikus trend (L) és a hidrosztatikus trend a felszíntől az izolációs mélységig $(2,6$ $\mathrm{km}$ ), az „A” pontig lineáris, de ettốl kezdve a pórusfolyadék nyomása $(\mathrm{P})$ nem emelkedik a litosztatikus gradiensnek $(23$ $\mathrm{MPa} / \mathrm{km}$ ) megfelelően, hanem annál valamivel kisebb. Ennek oka az lehet, hogy némi fluidum „elszivárgás” azért van a pórustérből, a pórusfluidum nem teljesen izolált, ezért a fluidum nyomása kisebb lesz, nem alakul párhuzamosan a litosztatikus gradienssel $(23 \mathrm{MPa} / \mathrm{km})$. A horizontális nyomás mélységtrendje sem tekinthetô lineárisnak, főleg a mélyebb, magasabb hômérsékletú részeken. A Poisson-arány a mélység növekedésével nó (PRICE 1959). Ez a trend azt eredményezi, hogy a mélység, illetve a hômérséklet növekedésével a horizontális nyomást egyre „nehezebben” éri el a fluidum nyomása. A Budafa területen létesített mélyfúrásoknál a fúrócserék alkalmával azt tapasztalták, hogy a kiépítés és a fúrócsere után a fúrórudazat leengedése a mélyen fekvő nyitott szakaszokban, ahol a hőmérséklet már magas volt, akadályba ütközött, mert a pelitek deformálhatósága megnövekedett, és ennek következtében a fúrólyuk „összeszúkült": ún. utánfúrást kellett alkalmazni. Ennek oka a fúrólyukat övezó pelitek deformációja volt annak következményeként, hogy a deformálhatóságukra jellemző Poissonarány a lineáristól eltéróen megnövekedett.

Említésre méltó, hogy a megfelelóen nagy fluidumnyomás (P) képes arra, hogy a pelit szemcséit kissé „összezsugorítsa", és ezáltal a pórusteret megnövelje, amelynek következményeként a fluidumnyomás csökken. A horizontális nyomás emiatt nagyobb lesz, mint a Terzaghi-egyenletnek megfelelő horizontális nyomás (MILLER 1995, BURRUS 1998). A megnövekedett horizontális nyomás következtében, azonos izolációs mélységet feltételezve, a pelit megrepedése és a primer migráció nagyobb mélységben jön létre.

A túlnyomás létrejötte az előzőekben részletezett mechanikai-szilárdságtani okokon kívül indokolható még azokkal, amelyek a pórustérbe zárt fluidum térfogat-növekedése miatt állnak elő: a víz hômérséklet-növekedés okozta térfogatnövekedéséből adódó akvatermális nyomással, a szénhidrogének képződése miatt bekövetkező térfogat-növekedéssel és az ásványi átalakulásokkal (SwARBRICK \& OSBORNE 1998).

Az akvatermális nyomás a tökéletesen zárt (izolálódott) pórusvízben alakul ki, mert a pórusvíz az üledékképződés során nagyobb mélységbe, magasabb hőmérsékletre kerülve nem tud a hốtágulásának megfeleló mértékben nagyobb térfogatot elfoglalni - súrúsége változatlan marad, a pórusvíz nyomása viszont megnő (BARKER 1972). Az akvatermális nyomás nagyságának kiszámításához egy hőmérsékletnyomás diagramot kell használni, amelyen a víz különbözó, de állandó sứrúséghez tartozó vonalai, az izo-sűrúség vonalak szerepelnek 1,000-0,877 t/ $\mathrm{m}^{3}$ intervallumban (KENNEDY \& HOLSER 1966). A 8. ábrán szemléltetett példával világítható meg az eljárás lényege. (Az ábrán csak egy izo-sứrúség vonal szerepel.) Tételezzük fel, hogy egy pelitben lévố fluidum 2,6 km mélységben éri el azt az állapotot, amelyben a fluidum már nem képes távozni a pelitből. A fluidum nyomása ennek megfelelően $26 \mathrm{MPa}$ (a 8. ábrán $\left.\mathrm{P}_{1}\left[\mathrm{z}_{\mathrm{A}}\right]\right)$. A hőmérséklet a jelzett mélységben $127^{\circ} \mathrm{C}\left(\mathrm{a} 8\right.$. ábrán $\left.\mathrm{T}_{1}\right)$, ha a figyelembe vett geotermikus gradiens $45^{\circ} \mathrm{C} / \mathrm{km}$ és a felszíni hômérséklet $10^{\circ} \mathrm{C}$. A víz nyomás-hőmérséklet diagramján (8. ábra) az említett nyomás- és hőmérsékletértékeknek $0.95 \mathrm{t} / \mathrm{m}^{3}$ sưrúségú víz felel meg. Ez a kiindulási adatpár $\left(26 \mathrm{MPa}, 127^{\circ} \mathrm{C}\right) \mathrm{az}$ „A” pontot határozza meg (2., 7. és 8. ábra). Tételezzük fel, hogy az üledékképződés során 


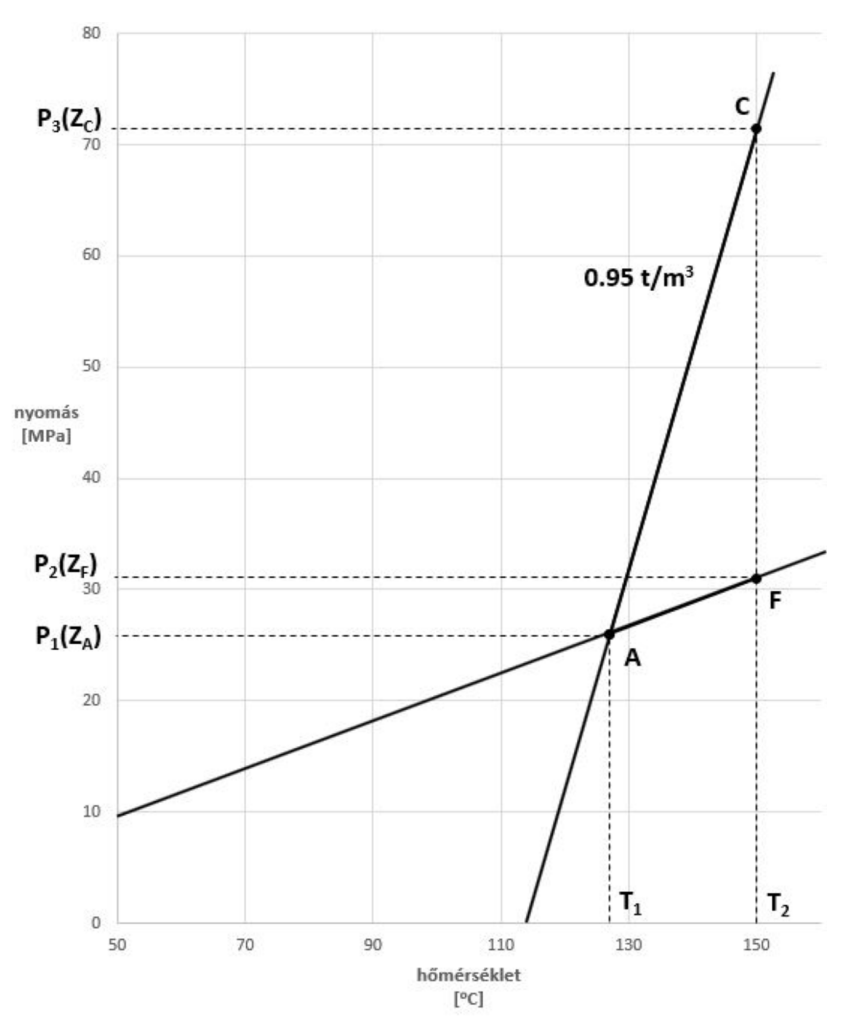

8. ábra. A víz nyomás-hőmérséklet diagramja

Figure 8. Pressure-temperature diagram of water

a pelit 0,5 kilométerrel mélyebbre kerül, azaz 3,10 km mélységben lesz, ahol a hőmérséklet $150{ }^{\circ} \mathrm{C}\left(8\right.$ ábra $\left.\mathrm{T}_{2}\right)$. Ha hidrosztatikus viszonyok lennének, akkor a 3,10 km mélységnek megfelelő nyomás $31 \mathrm{MPa}$ lenne (8. ábra $\left.\mathrm{P}_{2}\left[\mathrm{z}_{\mathrm{F}}\right]\right)$. A $150{ }^{\circ} \mathrm{C}$ hőmérséklet $\left(\mathrm{T}_{2}\right)$ és a $31 \mathrm{MPa}$ nyomás $\left(\mathrm{P}_{2}\left[\mathrm{z}_{\mathrm{F}}\right]\right)$ szolgáltatja a 7. és 8 . ábrán lévő „F” pontot. Tehát ha a 2. ábrán jelzett hidrosztatikus viszonyoknak megfelelő mélységtrend $(\mathrm{N})$ lenne érvényes, akkor a $0,5 \mathrm{~km}$ nagyságú süllyedéshez $5 \mathrm{MPa}$ nyomásemelkedés $\left(\mathrm{P}_{2}\left[\mathrm{z}_{\mathrm{F}}\right]-\mathrm{P}_{1}\left[\mathrm{z}_{\mathrm{A}}\right]\right)$ tartozna. Azonban zárt térben a víz súrúsége (ez esetben $0,95 \mathrm{t} / \mathrm{m}^{3}$ ) nem változik, és a $150{ }^{\circ} \mathrm{C}$ hőmérsékletnek a „C” ponthoz tartozó nyomás $\left(\mathrm{P}_{3}\left[\mathrm{z}_{\mathrm{C}}\right]\right)$, azaz $71,4 \mathrm{MPa}$ felel meg. $\mathrm{Az}$ akvatermális nyomás a „C" és az „F” pontokhoz tartozó nyomásértékek különbsége $\left(\mathrm{P}_{3}\left[\mathrm{z}_{\mathrm{C}}\right]-\mathrm{P}_{2}\left[\mathrm{z}_{\mathrm{F}}\right]\right)$, azaz 40,4 MPa. A $0,5 \mathrm{~km}$ nagyságú süllyedés esetén az akvatermális nyomás gradiense $80,8 \mathrm{MPa} / \mathrm{km}$, a litosztatikus (23 MPa/km) és a hidrosztatikus (10 MPa/km) nyomásgradienseknél jóval nagyobb. Az akvatermális nyomás 2,814km mélységben (2. ábra „G” pont) éri el a horizontális nyomást, ahol a pelit megrepedezik, és a primer migráció végbemegy. (A 7. ábrán az „A” és a „G” pontokat összekötő egyenes szemlélteti az effektív nyomás változását (E') az akvatermális nyomás hatására.) Ugyanazon izolációs mélységből (2,6km) kiindulóan a litosztatikus trenddel párhuzamos fluidumnyomástrend 4,45 km, az akvatermális trend 2,814 km mélységben hozza létre a primer migráció feltételét a nem egyensúlyi kompakcióból eredő túlnyomásos állapotban, a pelitek megrepedését. Belátható, hogy - összehasonlítható körülmények között - az akvatermális nyomás annál nagyobb, minél nagyobb a geotermikus gradiens.
A hazai mély neogén süllyedékekben mért túlnyomásértékek arra utaltak, hogy a túlnyomás létrejöttében a nem egyensúlyi kompakcióból származó túlnyomás mellett jelentős szerepe lehetett az akvatermális nyomásnak (SzALAY 1980). Az izoláció utáni nyomásnövekedés az adatok szerint lényegesen nagyobb volt, mint a nem egyensúlyi kompakcióból eredő lett volna. Ezt a szerzők az akvatermális nyomás hatásának tulajdonították. A Gulf Coast területén hasonlóan nagy volt az akvatermális nyomás szerepe a túlnyomás kialakulásában (MAGARA 1975b). A Gulf Coast adatai szerint az akvatermális nyomás hatékonyabban növeli meg a túlnyomást, ha a pórusfolyadék izolációja mélyebben következik be, ahol a pelitek áteresztôképessége igen kicsinnyé vált, továbbá ha az üledékképződés sebessége nagy: ilyen körülmények között kevesebb pórusfolyadék tud a pelitből elszivárogni, és így a létrejött túlnyomás tartósabban megmarad. Például, ha a $0,5 \mathrm{~km}$ nagyságú süllyedéshez tartozó üledékképződési sebesség millió évenként 0,1 km, akkor a süllyedés 5 millió év alatt következik be. Ugyanez a süllyedés a millió évenkénti 1 km esetén csak 0,5 millió évet igényel, az előbbi egytizedét. Az igen alacsony áteresztôképességnek megfelelő állapotban az elszivárgás lehetőségeit csökkenti az, hogy ilyen tömött kőzetekben az egymással nem elegyedő két fázis együttesen nem képes mozogni. Ezt szemlélteti a 6. ábra „b” része, amelyen látható a „III b” jelû szakasz, ahol két fázis nem mozoghat együtt (SHANLEY 2004). Ez a ,permeabilitásgát” csökkenti az elszivárgást. A szakemberek egy része megkérdőjelezi azt, hogy az akvatermális nyomás jelentős lehet (ChapMan 1980, LuO \& VASSEUR 1992). CHAPMAN (1980) cikkének diszkussziójában BARKER \& HoRSEFIELD (1982) olyan adatokat közölt a Mexikói-öböl területéról, amelyek az akvatermális nyomás hatására utalnak: a nyomásadatok a nyomás-hőmérséklet diagramban az akvatermális nyomásnak megfelelő izo-sürüség vonalra estek.

Az üledékképződés során egyre nagyobb mélységbe és magasabb hőmérsékletre kerülő pelitek szerves anyagának, a kerogénnek a termikus átalakulása is megnöveli a pórusokban lévő fluidum térfogatát, így zárt térben a vízhez hasonlóan megnöveli a fluidum nyomását. Az olaj képződése a kerogénből még nem hoz létre jelentős térfogat-növekedést (MUDFORD \& BEST 1989). Magasabb termikus érettségnél azonban a gázképződés nagy térfogat-növekedést eredményez (MEISSNER 1978). A kőzetek szerves anyagának egyik határozott alakú elemének, a vitrinitnek a nagy térfogat-növekedéssel járó termikus átalakulását gázzá fékezi a nyomás növekedése (CARR 1999). A kerogénből történő gázképződésnél nagyobb hatást feltételeztek abban az esetben, ha a már képződött olaj alakul át gázzá krakkolás révén (LUO \& VASSEUR 1996). A gázképződés által okozott túlnyomás feltételezett jelentős hatását korlátozza a LE CHATELIER elv, mely szerint a térfogat-növekedéssel járó folyamatokat gátolja a nyomás növekedése (ERDEY-GRÚZ 1963, OSBORNE 1997, KonCz 2010a).

$\mathrm{Az}$ ásványi átalakulásokhoz tartozik a kevert rétegú agyagásványok, a szmektitek vízvesztése és illitté változása (MAGARA 1975a). A nyomás növekedését izolált rendszerben az okozza, hogy az agyagásványokhoz kötött víz na- 
gyobb sûrűségú, mint a pórusokban lévő szabad, agyagásványokhoz nem kötött víz. Abban a hômérséklet-tartományban $\left(70-150{ }^{\circ} \mathrm{C}\right)$, amelyben az agyagásványok átalakulnak, a kötött víz felszabadul, és növeli a víz térfogatát, megnövelve ez által a pórusfolyadék nyomását (SwARBRICK \& OsBORNE 1998). A szmektitek átalakulásából eredő hatás azonban függ a pelit szmektittartalmától, valamint a pórusvízben lévő káliumionok megfelelő mennyiségben való jelenlététől, ami az illitté alakuláshoz szükséges.

A nagyobb mélységben lévő pelitekből történő primer migrációt előidézô túlnyomás képződését és fokozódását befolyásoló tényezők közül a leghatékonyabbnak a nem egyensúlyi kompakcióból eredőt tartják (SWARBrick \& Osborne 2002). Azok az adatok azonban, amelyek a Gulf Coast és Magyarország területéról származnak, arra utalnak, hogy jelentős szerep tulajdonítható az akvatermális nyomásnak is (MAGARA 1975b, SZALAY \& KonCZ 1980). Bármilyen természetú hatásról is legyen szó, akár a nem egyensúlyi kompakcióról, beleértve az akvatermális nyomást is, akár a képződött olajról és gázról, vagy az ásványi átalakulásokról, a nyomásnövekedés és -megmaradás, valamint a pelitek megrepedése miatt előállt nagy áteresztőképesség következtében létrejövő primer migráció szempontjából az a kedvező, ha minél kisebb az áte-resztőképesség és minél nagyobb az üledékképződés üteme.

\section{Primer migráció a középsố-miocén anyaközetekben}

Genetikai korrelációk segítségével megállapítható volt, hogy a Budafa és Lovászi mezôk könnyú olaja a középső-miocén anyakőzetekben képződött (KoNCZ 2017). Mind Budafa, mind Lovászi esetében a készletek zöme 1085-1252, illetve 1100-1440 m mélység-intervallumban, főként a pannóniai emelethez tartozó üledékképződés mélyvízi kifejlődésében (az ,alsópannon” képződményekben) lévő turbidites homokkőtárolókban halmozódott fel. A Budafa mező olaja a „B2” jelü badeni, a Lovászié a „K” jelú kárpáti anyakőzetekben keletkezett a genetikai korrelációk eredményei szerint és vertikális migráció révén halmozódott fel az anyakőzeteknél jóval kisebb mélységben lévő tárolókőzetekben (9. ábra). Felmerül a kérdés. hogy a középső-miocén anyakőzetekben képződött olaj milyen folyamat révén, mikor távozott el anyakőzetéből a primer migráció során.

Az aromás vegyületek közül a metilfenantrének alkalmasak az olajok termikus érettségének számszerú megadására vitrinitreflexió egyenérték formájában (RADKE \& WELTE 1983). A Budafa mező olajaiból mért 21 érték átlaga

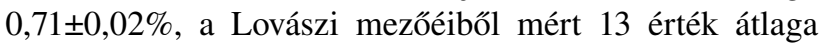
$0,90 \pm 0,04 \%$. Az igen kicsiny szórásértékek $(0,02$, illetve 0,04\%) arra engednek következtetni, hogy az olajok primer migrációja egyetlen, idejét és mélységét illetően eléggé behatárolt esemény következményeként, „hirtelen” ment végbe. Arra nézve, hogy ez az esemény mindkét esetben

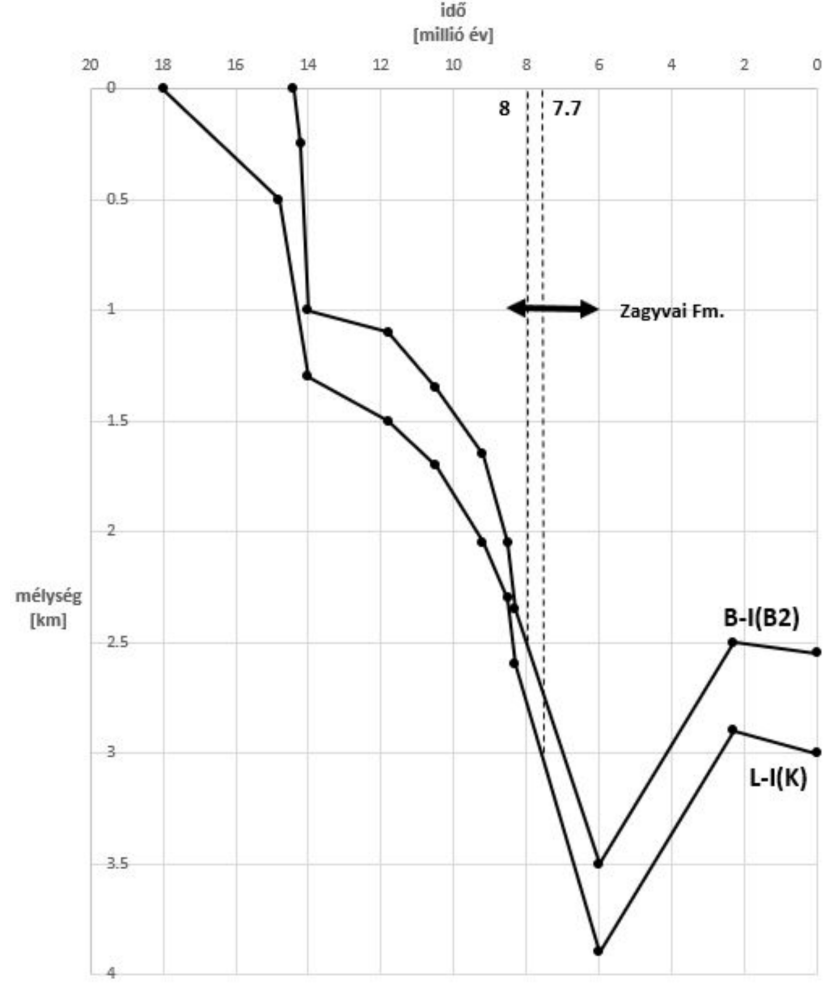

9. ábra. A középső-miocén anyakőzetek eltemetődési története Figure 9. Burial history of Middle Miocene source rocks

ugyanaz vagy eltérő volt-e, itt még most nem lehet választ adni. A válasz az alábbiakban részletezett medencemodellszámítások eredményeitől várható.

A Budafa-I és a Lovászi-I fúrás profiljában végrehajtott medencemodell-számítások kiindulási eleme az eltemetôdéstörténet volt: a Budafa-I fúrás esetében a „B2” jelű, jelenleg 2,3-2,8 km mélységintervallumban lévô badeni korú képződmények „,közepére” (2,55km), a Lovászi-I fúrásnál a jelenleg 2,5-3,5 km mélységintervallumban lévő kárpáti képződmények ,közepére” (3km) vonatkozóan (9. ábra). (A medencemodell-számítások során $45{ }^{\circ} \mathrm{C} / \mathrm{km}$ geotermikus gradiens, $10{ }^{\circ} \mathrm{C}$ felszíni hőmérséklet és $40-80 \mathrm{~mW} / \mathrm{m}^{2}$ értéktartományú hőáram nyert alkamazást.) Indokoltan feltételezhetô volt, hogy 6,0-2,4 millió év idôtartományban ment végbe a medence inverziója, amelynek során a alluviális síksági Zagyvai Formációból $1 \mathrm{~km}$ vastagságú rész erodálódott. Az inverzió folyamán erodálódott képződmények vastagságát oly módon is meg lehet becsülni, hogy összehasonlítjuk az azonos termikus érettségnek megfelelő mélységértékeket. Nyilvánvaló, hogy a nagyobb mélységben lévő, ugyanazon érettségi szint a nem invertált medencerészekre, a jóval kisebb mélységben lévő, az előbbivel azonos érettségi szint az invertáltakra utal. A délkelet-alföldi mély neogén medencékben a 0,6\% értékú vitrinitreflexióval jellemzett érettségi szint 2,6-2,8 km, Budafa-Lovászi térségében ennél jóval kisebb, 1,9-2,0 km mélységben van. A képződött szénhidrogéneket tartalmazó kőzetextraktum (bitumen) szervesszén-tartalomra vonatkoztatott értékének, a bitumen-koefficiensnek a maximuma a délkelet-alföldi fúrásokban $4 \mathrm{~km}$, a Budafa-Lovászi területen 


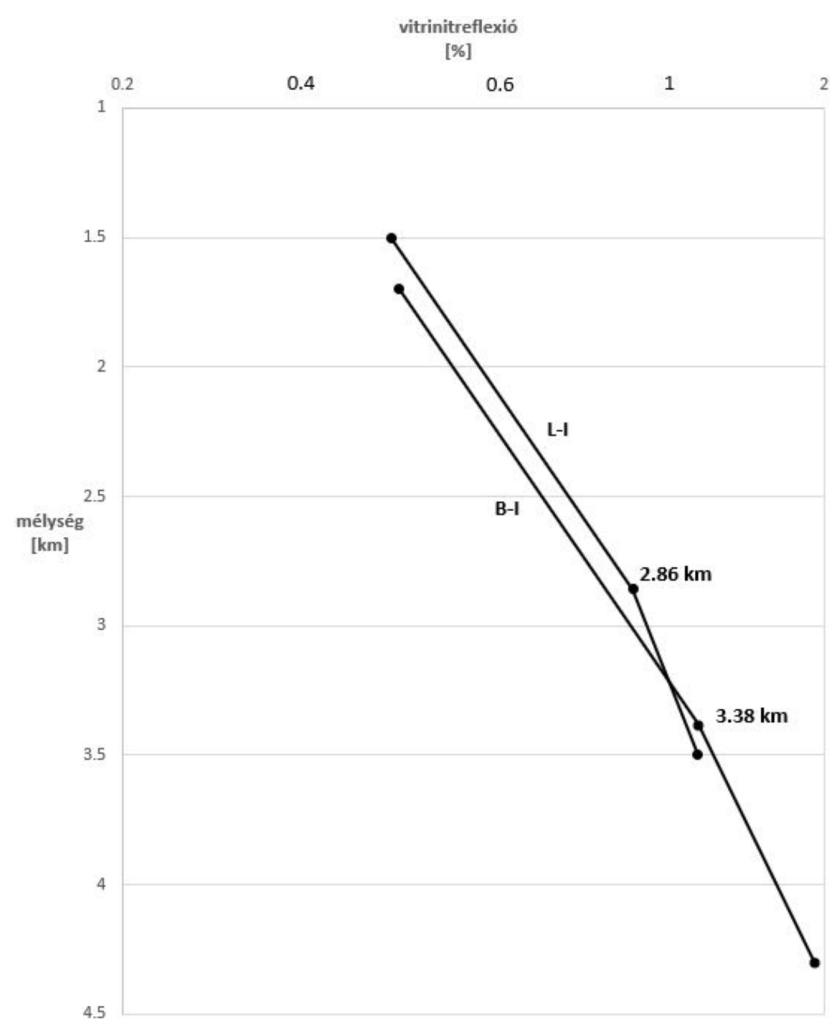

10. ábra. Vitrinitreflexió-mélység összefüggések a B-I és a L-I fúrásokban Figure 10. Vitrinite reflectance vs. time relationships in $B-I$ and $L-I$ boreholes

ennél jóval kisebb, 2,6 km mélységben mutatkozott (SzALAY 1980).

A medencemodell-számítások helyességének ellenőrzésére szolgáló módszerek egyike a modellezett területet képviselő fúrásban mért és a modellezés eredményeként elóállt vitrinitreflexióknak az összehasonlítása (10. ábra). A BudafaI (B-I) fúrás 1,7-4,35 km intervallumából 35, a Lovászi-I (LI) fúrás 1,56-3,505 km intervallumából 25 vitrinitreflexióadat állt rendelkezésre. A 10. ábrán a B-I és a L-I fúrásokra vonatkozóan a vitrinitreflexió logaritmusa $\left(\operatorname{lg~}_{0} \%\right)$ szerepel a mélység $(\mathrm{z} \mathrm{km})$ függvényében: a vitrinitreflexió logaritmusa lineárisan változik a mélységgel folyamatos üledékképződés esetén a lg $\mathrm{R}_{0}=$ (konstans) $)_{1} \mathrm{z} \mathrm{z}$ ( konstans) $)_{2}$ egyenlet szerint. Látható, hogy mindkét fúrásnál két, egymástól eltérô meredekségú szakasz mutatkozik. A B-I fúrásnál 3,378 km, a L-I fúrásnál 2,86 km mélységtől, 1,32, illetve $1,07 \%$ vitrinitreflexiótól kezdődóen a meredekség kisebb $(0,180$, illetve $0,143 \% / \mathrm{km})$, mint a sekélyebb részeken $(0,254 \% / \mathrm{km})$. A mélyebb zónákban észlelt kisebb meredekség valószínúleg annak következménye, hogy a jelentôs túlnyomás visszaszorítja a vitrinitek gázzá alakulásának folyamatát, a vitrinitreflexió növekedését (CARR 1999). A medencemodell-számításokkal nyert, számított (SwEENEY \& BuRNHAM 1990) és a mért vitrinitreflexiók elég jól egyeznek. A B-I fúrásnál a medencemodell-számításokkal nyert és a mért vitrinitreflexiók különbsége 0,09-0,18\%, a L-I fúrásnál 0,04-0,08\% intervallumban van. A mért vitrinitreflexiók kisebb meredekségú tartományában az említett különbség nagyobb, 0,20\% feletti. Ennek az lehet az oka, hogy az alkalmazott Petromod

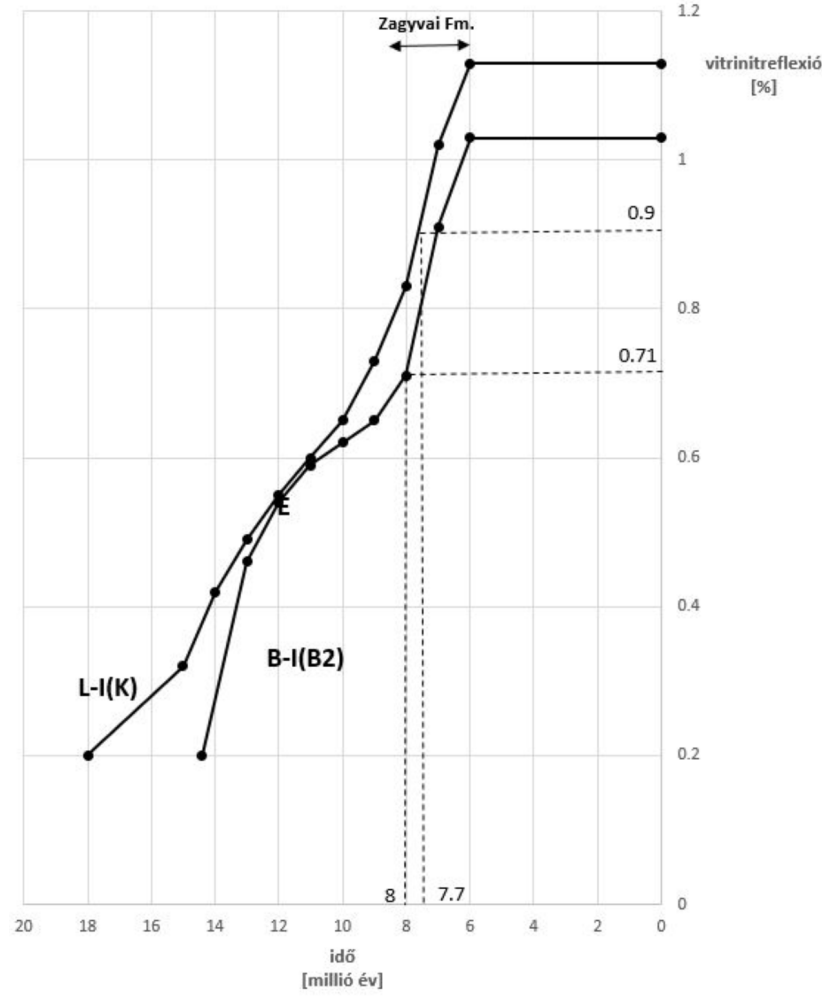

11. ábra. Vitrinitreflexió-idő összefüggések a középső-miocén anyakőzetekben Figure 11. Vitrinite reflectance vs. time relationships of Middle Miocene source rocks

szoftver nem tudta figyelembe venni a nyomás hatását a vitrinitek gázzá alakulására.

A medencemodell-számítások eredményeként elô lehetett állítani a B-I és a L-I fúrások badeni (B2), illetve kárpáti (K) anyakőzeteiben a vitrinitreflexió változását az idő függvényében (11. ábra). A Budafa mezó olajaiban mért metilfenantrén izomerarányokból számított vitrinitreflexió egyenértéket $(0,71 \%)$ 8,0 millió évnél, a Lovászi mező olajainak megfelelőt $(0,90 \%) 7,7$ millió évnél, a Zagyvai Formáció lerakódása idején érik el az anyakőzetek. A két idôpont, amikor az anyakőzeteknek meg kellett repedniük, egymáshoz igen közeli, egy és ugyanazon eseményhez, a Zagyvai Formáció képződéséhez köthetô, amikor a középsô-miocén anyakôzetek termikus érettsége gyorsabban növekszik a nagy üledékképződési sebesség miatt. A Zagyvai Formáció képzôdése a modellezés bemenô adata szerint 8,3 millió évtôl 6,0 millió évig tartott: ez utóbbi idôpont azonban lehetett akár 7,5 millió év is. Ez esetben az üledékképződési sebesség jóval nagyobb, a B-I fúrásnál $1425 \mathrm{~m} /$ millió év, a L-I fúrás esetében $1655 \mathrm{~m} /$ millió év a 496, illetve 576 m/millió év helyett. Az eltemetôdési történet során a badeni, illetve kárpáti anyakőzetek, a Szolnoki, Algyối, Újfalui és Zagyvai Formáció képződése idején kerültek 2 kilométernél nagyobb mélységbe, ahol a pelitek áteresztôképessége már igen kicsinnyé $(<0,1 \mathrm{mD})$ válhatott. Ezek közül a Zagyvai Formáció képzôdési idejének nagyobb voltával $(8,3-6$ millió év), illetve nagy üledékképződési sebességével túnik ki, amennyiben feltételezzük, hogy az üledékképződés 7,5 millió évnél befejeződött, és ami után elkezdődött a meden- 
ce inverziója, valamint a Zagyvai Formáció eróziója. Meg kell jegyezni, hogy a szakemberek az inverziót későbbre, a jelenhez közelebbre teszik.

Az eltemetôdéstörténet alapján a B-I fúrásban a badeni anyakőzet (B2) 2,52 km mélysége felel meg a primer migráció időpontjának, a 8 millió évnek. A L-I fúrásban a kárpáti anyakőzet (K) 2,94 km mélységéhez tartozik a primer migráció időpontja, a 7,7 millió év.

Magyarázatra szorul az a genetikai korrelációk eredményeivel alátámasztott tény, hogy a Budafa szerkezetben csak a badeni, a Lovászi szerkezetben viszont csak a kárpáti anyakőzetekben képződött szénhidrogének halmozódtak fel. Az előzőekben ismertetett megfontolások szerint a badeni és a kárpáti anyakőzetekben a primer migráció egy és ugyanazon esemény, a vastag Zagyvai Formáció gyors lerakódásának következménye lehetett. Mivel mind a Budafa, mind a Lovászi szerkezet alatt lévô migrációs gyújtôkörzetben létezik mindkét anyakőzet, a sekélyebben lévő turbidites homokkőtárolókba mindkét anyakőzet szénhidrogénjeinek el kellett volna jutniuk vertikális migráció révén, és ott elegyedett formában kellett volna jelen lenniük. A különbség a Budafa és Lovászi terület között döntően abban rejlik, hogy a kárpáti tetőnek megfelelő képződmény, a glaukonitos homokkő migrációt gátló záróelemként viselkedik Budafán, Lovásziban viszont ez a záróképződmény hiányzik. Budafán a glaukonitos homokkő és az alatta lévő képződmények túlnyomásosak, a glaukonitos homokkő felettiek hidrosztatikus nyomásúak: a glaukonitos homokkő meggátolta a kárpáti eredetû szénhidrogének eljutását a sekélyebb, turbidites homokkőtárolókba. Lovászi esetében ez nem történhetett meg a glaukonitos homokkő hiánya miatt, viszont az a probléma, hogy miért csak a kárpáti eredetű szénhidrogének halmozódtak fel vertikális migráció, vetôk révén a sekélyebben fekvő turbidites homokkövekben, a badeni eredetúek miért nem képeztek akkumulációkat. Feltételezhetô, hogy a mélyebben fekvő, nagyobb nyomással rendelkezô kárpáti eredetû szénhidrogén-fluidumok meggátolták a kisebb mélységben lévő, alacsonyabb nyomású, badeni eredetúek bejutását a vetősíkok által biztosított migrációs vezetőközegbe. Említésre méltó, hogy a primer migráció, illetve a Zagyvai Formáció lerakódása idején már jelen voltak a pannóniai emelet mélyvízi képződményei, a turbidites homokkövek, amelyekben Budafán a badeni, Lovásziban a kárpáti eredetû szénhidrogének így fel tudtak halmozódni.

\section{Primer migráció az Endrődi Formációban}

Az átlagosan 100-200 m, de 700 métert is meghaladó vastagságú, nyíltvízi márgákból álló Endrődi Formáció olyan anyakőzet, amelyben a képződött szénhidrogének genetikai jellemzői lényegesen eltérőek a középső-miocén anyakőzetekben képződöttekétől, így egymástól megkülönböztethetôk (KoNCZ et al. 2010b). Az alaphegységi kiemelkedések fölött az abráziós partmenti konglomerátumból és homokkőbool álló Békési Formációra, másutt az általában középső-miocén képződményekből összetevődő prepan- nóniai korúakra települ (JuHÁsz 1998). Annak ellenére, hogy a neogén mélymedencékben olyan mélységben van, ami lehetôvé tehette az olajképződést, a bennük képződött szénhidrogének a szerkezetekben nem képeztek jelentôs készletû telepeket: általában olajnyomok fordultak elő, illetve a palaolaj (shale oil) kitermelésre nyújtanak lehetôséget a nem hagyományos előfordulások körén belül (KoNCZ 2019b). Ez igaz a Makói-árokra és a tágabb környezetében lévő Algyő szerkezetre is. A Makói-árok nem tartalmaz középsőmiocén képződményeket: az aljzatot az Endrődi Formáció pelitjei fedik (SzUROMI-KorEcz et al. 2004). A Makói-árok nyugati szélén felfedezett felhalmozódások olaj-szénhidrogénjei nem mutattak genetikai rokonságot a Makói-árokban mélyült Hódmezővásárhely-I (Hód-I) fúrásban megismert anyakőzet, az Endrődi Formáció szénhidrogénjeivel: az algyői olajok nem származhatnak a Makói-árok anyakőzeteiből (SAJGó 1984). A későbbi genetikai korrelációk eredményei is ezt támasztották alá (KoNCz 2018). A 2004-2007 években a kanadai Falcon cég leányvállalataként múködő TXM Kft. próbálkozott meg a Makói-árokban feltételezett ún. medenceközponti földgáz-előfordulás (BCGA - basincentered gas accumulation) fúrásos kutatásával a későbbi kitermelés reményében. Feltételezték, hogy a mélyvízi turbidites homokkőrétegektől kezdődően az üledékek pórustere teljesen telítve van földgázzal (BADICs 2010, BADICS et al. 2011). A fúrások a feltételezett nagy mennyiségú kitermelhető földgázt illetően nem igazolták ezt a feltételezést.

A Hód-I fúrásban a porozitásértékek normál, hidroszta-

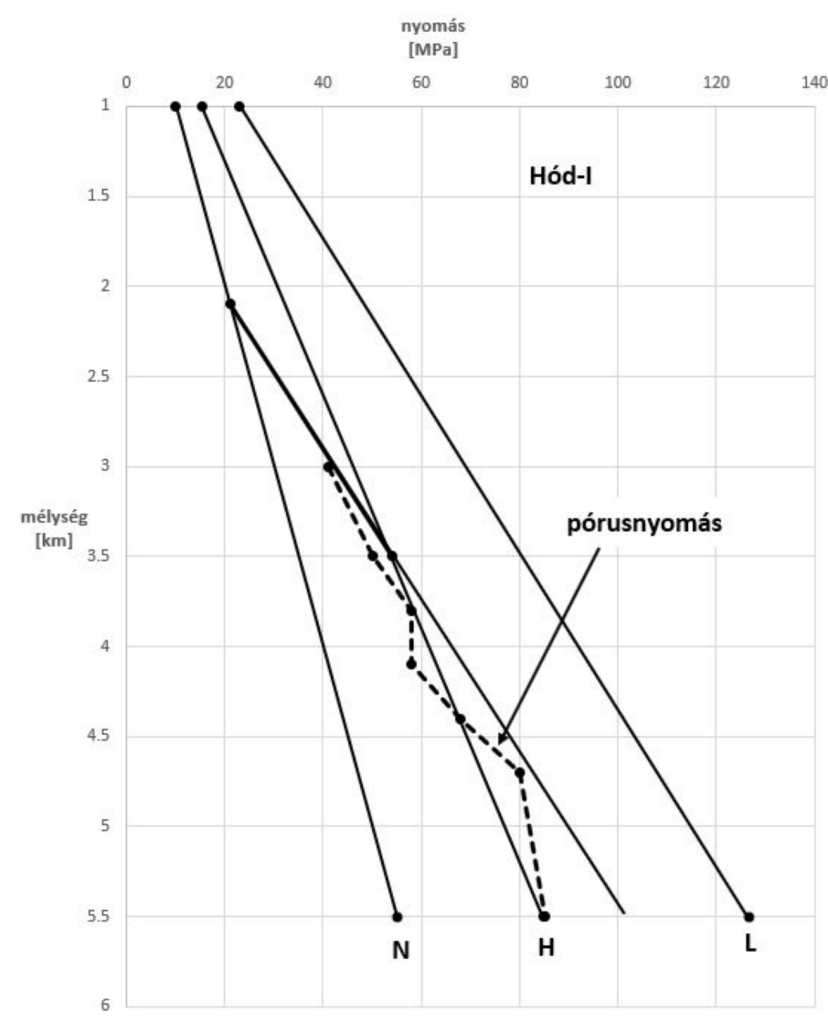

12. ábra. Számított pórusnyomásértékek a Hód-I fúrásban (SZALAY 1982) Figure 12. Calculated pore pressure values in Hód-I borehole (SZALAY 1982) 
tikus nyomással jellemezhetô eredményező trendje 2,1 km mélységben megszúnik, és nagyobb mélységekben ezt a trendet nem követi: a képződményekben 2,1 km mélységtől kezdődően a nem egyensúlyi kompakciónak megfelelően túlnyomás alakult ki (12. ábra) (SzALAY 1982). Ez a viszonylag kis mélységben kialakult izoláció feltehetôen annak következménye, hogy az Endrődi Formációra vonatkozóan az üledékképződés, illetve a nyomásnövekedés átlagos sebessége nagy (460 méter, illetve 10,5 MPa millió évenként). (BudafaLovászi területén a kárpáti képződményekre vonatkozóan jóval kisebbek, 170 méter, illetve 3,8 MPa millió évenként.) Feltûnő, hogy az izolációs mélység (2,1km) a Hód-I fúrásban sekélyebb pozícióban van, mint a délkelet-alföldi mélyfúrásokban meghatározott izolációs mélység (2,6km). Ez a Hód-I fúrásban létrejött korai, kis mélységben bekövetkezett izoláció olyan állapotban következett be, amikor a pelitek áteresztôképessége még nem csökkent eléggé kicsinyre. Viszont 2,1 km mélységtől kezdődően létrejött izolációt feltételezve a litosztatikus nyomásra jellemző $23 \mathrm{MPa} / \mathrm{km}$ mélységgradienssel párhuzamosan növekvő fluidumnyomás 3,5 km mélységben éri el a horizontális nyomás értékét. Ennek következtében a pelit megrepedhetett volna, és a képződött szénhidrogének a primer migráció révén távozhattak volna a pelitből, ha ezt nem akadályozza meg a pelittest fedő, illetve fekü részén kialakult ,záróréteg”. A felrepedést követően a pelit záródhat, és újból növekedhet a túlnyomás, megteremtve ezzel az újbóli megrepedés lehetôségét. Erre utal a 12. ábrán a pórusnyomás további növekedése 3,5 km-nél nagyobb mélységben. Lehet, hogy a „zárórétegek” megrepedése következtében végbement primer migráció során ,kiszabadult” termogén szénhidrogének jelentkeztek a Makó-3 fúrásban 2150 2350 m mélységben, ahová vertikális migrációval juthattak (HETÉNYI et al. 1993). Ebben a mélységtartományban, ahol a vitrinitreflexió $0,5 \%$ (a termikus átalakultság mértéke alacsony), legfeljebb bakteriális eredetű metán lehet jelen, termogén eredetű szénhidrogének csak vertikális migráció révén jelentkezhetnek. A 12. ábrán látható, hogy a pórusnyomás 4,4 km mélységtől kezdődően meghaladja a horizontális nyomást, azaz a felrepedés feltétele adott. A kérdés az, hogy ez megtörténhetett-e, ha a Poisson-arány a magas hőmérsékletnek megfelelően megnövekedett.

Figyelembe kell venni, hogy az Endrôdi Formáció vastag és homokkövekkel nem tagolt. Ennek azért van jelentősége, mert a formáció tetőzónája az óhatatlanul elszivárgó pórusfluidum miatt jobban kompaktálódik, mint a formáció belső része. Tehát a tetőzónában az ily módon lecsökkent áteresztôképesség megakadályozza a formáció belsejéből a pórusfluidum elszivárgását: a túlnyomás így fennmaradt, sôt fokozódott. A tetőzóna viszont felrepedhet a túlnyomás megfelelő mértékének elérésekor. Feltehető, hogy a Makó-3 fúrás kapcsán említett termogén szénhidrogének az Endrôdi Formáció tetőzónájából származnak. (Természetesen a pelittestek homokkővel, vagy az aljzattal érintkező fekü része is hasonlóan viselkedik.) A pelittest belsô része, még ha megrepedt is, nem képes szénhidrogéneket kibocsátani a homokkövek, illetve az aljzat felé a kompaktált, alacsony áteresztőképességú fedô és fekürészek miatt.
Az Endrődi Formáció felrepedése és a benne képződött szénhidrogének eltávozása a primer migráció során teljes bizonyossággal nem ítélhetô meg. Valószínúsíthetô azonban, hogy a korai, kis mélységben bekövetkező izoláció, a „zárórétegek” említett viselkedése, valamint a nagy mélységben, magas hőmérsékleten megnövekedő Poisson-arány következtében az Endrődi Formáció szénhidrogénjeinek csak egy elenyészô töredéke tudta elhagyni anyakőzetét, amelyek a nagy tömegú anyakőzet kis hányadát képező fedő, illetve fekü részekből származnak.

\section{Következtetések}

A középső-miocén anyakőzetek és az Endrődi Formáció mint anyakőzet viselkedése lényegesen eltérő. Az eltérések egy része azzal függ össze, hogy a középső-miocén anyakőzetek vékonyak, homokkövekkel tagoltak, míg az Endrődi Formáció vastag, homokkövekkel nem tagolt. Ez a különbség már az egyensúlyi kompakció stádiumában befolyásolja a vizes közegú primer migráció hatékonyságát: az anyakőzet egységnyi térfogatára vonatkoztatva, egyébként azonos feltételek között, a vékony, tagolt anyakôzetekből, így a középsô-miocén anyakőzetekből több szénhidrogén képes távozni, mint a vastag, tagolatlan anyakőzetből, az Endrődi Formációból. A vastag és tagolatlan anyakôzetek a nem egyensúlyi kompakció során is eltérő módon viselkednek. Fedő és fekü részeiken, ahol az óhatatlan elszivárgás miatt tömörödés és az áteresztôképesség csökkenése még lehetséges, kialakul egy olyan „,kéreg”, amely zárókőzetként szerepelve nem engedi meg a fluidumok elszivárgását a pelittest belsejéből. Ennek az a következménye, hogy a pelittest belseje hamar túlnyomásossá válik, és a túlnyomás egy bizonyos mértékének elérésekor megrepedezik, de az említett kéreg jelenléte miatt a pelit belsejéból fluidum nem képes távozni.

A középsô-miocén anyakôzetek Budafa-Lovászi területén akkor repedeztek meg, amikor a vastag Zagyvai Formáció rakódott le. A nagy üledékképződési sebesség miatt kevés idő állt rendelkezésre ahhoz, hogy érdemi elszivárgás mehessen végbe. Ez az állapot oly mértékben megnövelhette a túlnyomást, hogy az izolációs mélységnél nem sokkal nagyobb mélységben megrepesztette az anyakőzeteket. A megrepedezett anyakőzetekből a primer migráció során keletkezett vetők révén jutottak a szénhidrogének jelenlegi csapdáikba.

A vastag és tagolatlan Endrődi Formáció pórustereiben lévő fluidumok már viszonylag kis mélységben izoláltakká váltak a folyamatosan nagy üledékképződési sebesség miatt. Ennek eredményeként a nem egyensúlyi kompakció révén a túlnyomás viszonylag kis mélységben jött létre. A fedô és fekü részeken kialakult ,záróréteg” megakadályozhatta a fluidumok távozását a pelittest belsejéből oly mértékben, hogy a pelitek belsô részének megrepedésekor sem tudtak a fluidumok eltávozni. Lehetséges, hogy a Makói-árok Endrôdi Formációjából érdemi felhalmozódások nem jöttek létre az algyői gerincvonulaton. Kevés szénhidrogén viszont elmigrálhatott a pelittest tömegéhez képest igen kis tömegú „zárórétegek” megrepedése miatt. 


\section{Irodalom - References}

BADICs B. 2010: 3D modellezés külföldi és magyarországi esettanulmányok alapján. - Doktori értekezés.

Badics B., Uhrin A., Vető I., Bartha A. \& SAJgó Cs. 2011: Medenceközponti földgáz-előfordulás elemzése a Makói-árokban. Földtani Közlöny 141/1, 445-468

BARKER, C. 1972: Aquathermal Pressuring - Role of Temperature in Development of Abnormal-Pressure Zones. - AAPG Bulletin 56/10, 2068-2071. https://doi.org/10.1306/819a41b0-16c5-11d7-8645000102c1865d

BARKer, C. \& Horsfield, B. 1982: Mechanical Versus Thermal Cause of Abnormally High Pore Pressures in Shales: Discussion. AAPG Bulletin 66, 99-100. https://doi.org/10.1306/03b59a30-16d1-11d7-8645000102c1865d

BRoOKs, J., CORNFORD, C. \& ARCHER, R. 1987: The role of hydrocarbon source rocks in petroleum exploration. - In: BROOKS, J. \& FLEET, A. J. (eds): Marine Petroleum Source Rocks, Geological Society Special Publication 26, 17-46. https://doi.org/10.1144/gsl.sp 1987.026.01.02

BuRRUS, J. 1998: Overpressure Models for Clastic Rocks, Their Relation to Hydrocarbon Explusion: a Critical Reevaluation. - In: LAW, B. E., UlmischeK, G. F. \& Slavin V. I. (eds): Abnormal pressures in hydrocarbon environments. - AAPG Memoir 70, 35-63. https://doi.org/10.1306/M70615C3

CARR, A. D. 1999: A vitrinite reflectance kinetics modell incorporation overpressure retardation. - Marine and Petroleum Geology 16, 355-377. https://doi.org/10.1016/s0264-8172(98)00075-0

ChAPMAn, R. E. 1980: Mechanical Versus Thermal Cause of Abnormally High Pore Pressures in Shales. -AAPG Bulletin 64, $2179-2183$. https://doi.org/10.1306/03b59a35-16d1-11d7-8645000102c1865d

DuRAND, B. 1983: Present trends in organic geochemistry in research on migration of hydrocarbons. - In: BJoRoY, M. et al. (eds): Advances in Organic Geochemistry 1981 Wiley, Chichester 117-128. https://doi.org/10.1016/0146-6380(88)90066-6

DURAND, B. 1987: Understanding of HC migration in sedimentary basins (present state of knowledge). - Organic Geochemistry 13/1-3, 445-459. https://doi.org/10.1016/b978-0-08-037236-5.50052-x

ERDEY-Grúz T. 1963: A fizikai kémia alapjai. - Múszaki Könyvkiadó, Budapest, 393 p.

HetÉNYI, M., KonCZ, I . \& SZALAY, Á. 1993: Organic geochemical evaluation of the Makó-3 borehole. - Acta Geologica Hungarica 36/2, 211-222.

Hobson, G. D. 1954: Some Fundamentals of Petroleum Geology. - London-New York-Toronto, Oxford University Press. https://doi.org/ 10.1017/S001675680006653X

HubBert, M. K. 1953: Entrapment of petroleum under hydrodinamic conditions. - Bulletin of American Association of Petroleum Geologist 37, 1954-2026. https://doi.org/10.1306/5ceadd61-16bb-11d7-8645000102c1865d

HunT, J. M. 1990: Generation and Migration of Petroleum from Abnormally Pressured Fluid Compartments. - AAPG Bulletin 74/1, 112. https://doi.org/10.1306/0c9b21eb-1710-11d7-8645000102c1865d

HunT, J. M. \& JAMIESON, G. W. 1956: Oil and organic matter in source rocks of petroleum. - AAPG Bulletin 40, 477-488. https:// doi.org/10.1306/5ceae3e8-16bb-11d7-8645000102c1865d

JuHÁsz GY. 1998: A magyarországi neogén mélymedencék pannóniai képződményeinek litosztratigráfiája. - In: BÉRCZI I. \& JÁMBOR Á. (szerk.): Magyarország geológiai képzódményeinek rétegtana. A MOL Rt. és a MÁFI kiadványa, Budapest, 469-483

KenNEDY, G. C. \& HolsER, W. T. 1966: Pressure-volume-temperature, and phase relations of water and carbon dioxide, Sec. 16. - In: Handbook of physical constants. - Geological Society of America Memoirs 97, 371-383. https://doi.org/10.1130/MEM97-p371

KonCz I. 2010: Nem-hagyományos földgáz-előfordulások kialakulásának feltételei heterogén felépítésű tömött homokkőösszletekben. Bányászati és Kohászati Lapok - Bányászat - Köolaj és Földgáz 143/5, 6-19.

Koncz I. 2017: Budafa- és Lovászi-mezők olajának származása. - Bányászati és Kohászati Lapok-Bányászat-Köolaj és Földgáz 150/5, 6-9.

Koncz I. 2018: Az algyői telepek szénhidrogénjeinek eredete és migrációs modellje. - Bányászati és Kohászati Lapok, Bányászat - Kóolaj és Földgáz 151/5-6, 17-23.

KonCZ I. 2019a: A vertikális migráció szerepe a hazai szénhidrogén-felhalmozódások feltöltődésében. - Földtani Közlöny 149/2, 163-174.

Koncz I. 2019b: A Battonya-Pusztaföldvár gerinc szénhidrogén-rendszerei. - Bányászati és Kohászati Lapok, Bányászat - Köolaj és Földgáz 152/2-3, 33-38.

Koncz I., Horváth Zs., Gellért B., Kajári M., Cota, L., Balen, M. \& Bigunac, D. 2010b: Az alsópannon és középsőmiocén anyakőzetek organikus fáciese a Dráva-medence északi szárnyán. - Medencefejlödés és geológiai erôforrások: víz, szénhidrogén, geotermikus energia, a Magyar Földtani Társulat vándorgyúlése, Szeged, Geolitera, 121-122.

LuO, X. \& VASSEUR, G. 1992: Contributions of compaction and aquathermal pressuring to geopressure and the influence of environmental conditions. - AAPG Bulletin 76, 1550-1559. https://doi.org/10.1306/bdff8a42-1718-11d7-8645000102c1865d

LuO X. \& VAsSEUR, G. 1996: Geopressuring Mechanism of Organic Matter Cracking: Numerical Modelling. - AAPG Bulletin 80/6, 856874. https://doi.org/10.1306/64ed88ea-1724-11d7-8645000102c1865d

MagaRA, K. 1975a: Reevaluation of Montmorillonite Dehidratation as Cause of Abnormal Pressure and Hydrocarbon Migration. AAPG Bulletin 59/2, 292-302. https://doi.org/10.1306/83d91c7c-16c7-11d7-8645000102c1865d

MAGARA, K. 1975b: Importance of Aquathermal Pressuring Effect in Gulf Coast. - AAPG Bulletin 59/10, 2037-2045. https://doi.org/ 10.1306/83d921db-16c7-11d7-8645000102c1865d

MagaRA, K. 1976: Water Expulsion from Clastic Sediments during Compaction - Direction and Volumes. - AAPG Bulletin 60/4, 543553. https://doi.org/10.35767/gscpgbull.26.1.123

MAGARA, K. 1978: The significance of the expulsion of water in oil-phase primary migration. - Bulletin of Canadian Petroleum Geology 26/1, 123-131. 
Magara, K. 1980: Agents for Primary Hydrocarbon Migration: A Review. - AAPG Bulletin 64, 33-45. https://doi.org/10.1306/ St10411C3

MaGARA, K. 1981: Mechanisms of Natural Fracturing in a Sedimentary Basin. - AAPG Bulletin 65, 123-132. https://doi.org/10.1306/ 2f919783-16ce-11d7-8645000102c1865d

MeIsSNER, F. F. 1978: Petroleum Geology of the Bakken Formation, Williston Basin, North Dakota and Montana. - In: 24th Annual Conference, Williston Basin Symposium: Montana Geological Society, 207-227.

Miller, T.W. 1995: New Insights on Natural Hydraulic Fractures Induced by Abnormally High Pore Pressures. - AAPG Bulletin 79/7, 1005-1018. https://doi.org/10.1306/8d2b21af-171e-11d7-8645000102c1865d

Miller, T. W., LuK, C. H. \& OlgaARD, D. L. 2002: The Interrelationships between Overpressure Mechanisms and In-Situ Stresses. - In: Huffman, A. R. \& Bowers, G. L. (eds): Pressure regimes in sedimentary basins and their prediction. AAPG Memoir 76, 13-20. https://doi.org/10.1306/m76870c2

MudFoRD, B. \& BEST, M. E. 1989: Venture gas field, offshore Nova Scotia: case study of overpressuring in region of low sedimentary rate. - AAPG Bulletin, 73, 1383-1396. https://doi.org/10.1306/44b4aa55-170a-11d7-8645000102c1865d

Osborne M. J. \& Swarbrick R. E 1997: Mechanisms for Generating Overpressure in Sedimentary Basins: A Reevaluation. - AAPG Bulletin 81/6, 1023-1041. https://doi.org/10.1306/8626D379-173B-11D7-8645000102C1865D

OzKaYA, I. 1984: Computer Simulation of Hydraulic Fracturing in Shales - Influences on Primary Migration. - Journal of Petroleum Technology 36/5, 826-828. https://doi.org/10.2118/11455-PA

Payne, D. F., TuncaY, K., PARK, A., Comer, J. B. \& Ortoleva, P. 2000: A Reaction-Transport-Mechanical Approach to Modeling the Interrelationships Among Gas Generation, Overpressuring, and Fracturing: Implications for the Upper Cretaceous Natural Gas Reservoirs of the Piceance Basin, Colorado. - AAPG Bulletin 84/4, 545-565. https://doi.org/10.1306/c9ebce4b-1735-11d7$8645000102 \mathrm{c} 1865 \mathrm{~d}$

PRICE, L. C. 1994: Basin richness and source rock disruption - a fundamental relationship? - Journal of Petroleum Geology 17, 5-38.

PRICE, N. J. 1959: Mechanics of jointing in rocks. - Geology Magazine 96, 149-167. https://doi.org/10.1111/j.1747-5457.1994.tb00112.x

RADKE, M. \& Welte, D. H. 1983: The methylphenanthrene index (MPI): A maturity parameter based on aromatic hydrocarbons. - In: BJoROY, M. (ed.): Advances in Organic Geochemistry 504-512.

Ronov, A. B. 1958: Organic carbon in sedimentary rocks (in relation to the presence of petroleum. - Geochemistry 5, 497-509.

RouCHET, J. 1981: Stress Fields, a Key to Oil Migration. - AAPG Bulletin 65, 74-85.

SAJGÓ, Cs. 1984: Organic geochemistry of crude oils from South-east Hungary. - Organic Geochemistry 6, 560-578. https://doi.org/ 10.1016/0146-6380(84)90079-2

Shanley, K. W., Cluff, R. M. \& Robinson, J. W. 2004: Factors controlling prolific gas production from low-permeability sandstone reservoirs: Implications for resource assessment, prospect development, and risk analysis. - AAPG Bulletin 88/8, 1083-1121. https:// doi.org/10.1306/03250403051

Somosvéri Zs. 1987: Geomechanika I. - Kézirat, Nehézipari Múszaki Egyetem, Bányamérnöki Kar, Tankönyvkiadó, Budapest, 182 p.

Swarbrick, R. E. \& Osborne, M. J. 1998: Mechanisms that Generate Abnormal Pressures: an Overview. - In: LAw, B. E., ULMISCHEK, G. F. \& SLAVIN V. I. Abnormal pressures in hydrocarbon environments. AAPG Memoir 70, 13-34.

Swarbrick, R. E., Osborne, M. J. \& YArdLEy, G. S. 2002: Comparison of Overpressure Magnitude Resulting from the Main Generating Mechanisms. - In: Huffman. A. R. \& Bowers, G. L. (eds): Pressure regimes in sedimentary basins and their prediction. AAPG Memoir 76, 1-12. https://doi.org/10.1306/M70615C2

SweEney, J. J. \& Burnham, A. K. 1990: A Simplified Arrhenius Model for Calculating Vitrinite Reflectance. - AAPG Bulletin 74, 1559_ 1570. https://doi.org/10.1306/0c9b251f-1710-11d7-8645000102c1865d

SzALAY Á. 1982: A rekonstrukciós szemléletû földtani kutatás lehetôségei a szénhidrogén-perspektívák elörejelzésében a DK-alföldi neogén süllyedékek területén. - Kézirat, kandidátusi értekezés.

SZALAY Á. \& KonCZ I. 1980: Szénhidrogén-képződési és -migrációs folyamatok a délkelet-alföldi és a Dráva süllyedékekben. - Köolaj és Földgáz 13 (113) / 6, 177-186.

Szuromi-Korecz, A., SÜTő-Szentai, M. \& Magyar, I. 2004: Biostratigraphic revision of the Hod-I well: Hungary's deepest borehole failed to reach the base of the upper Miocene Pannonian Stage. - Geologica Carpathica 55, 475-485.

TerZAGHI, K. 1923: Die Berechnung der Durchassigkeitziffer des Tones aus dem Verlauf der hydrodynamischen Spannungerscheinungen. - Sitzungbericht Akadamie Wissenschaft Wien, Mathematik Naturwissenschaft, Kl. Abteil 2A 132/(3-4), 125-138.

Kézirat beérkezett: 2020. 02. 03.

Online megjelent: 2020. 12. 